\title{
Alluvial landscape evolution: what do we know about metamorphosis of gravel bed meandering and braided streams
}

\author{
F METIVIER ${ }^{1}$ and L. BARRIER ${ }^{2}$
}

July 9, 2010

${ }^{1}$ Laboratoire de dynamique des fluides géologiques. Institut de Physique du Globe de Paris (IPGP, UMR 7154, CNRS, Univ. Paris Diderot), metivier@ipgp.jussieu.fr

${ }^{2}$ Laboratoire tectonique. Institut de Physique du Globe de Paris (IPGP, UMR 7154, CNRS, Univ. Paris Diderot),barrier@ipgp.jussieu.fr

As the science of sediment transportation and deposition develops, it will be possible to predict more and more closely the morphological changes which will take place in a river due to any set of conditions and rate at which they will occur.

Lane (1955, p. 745-6.)

Often all the modern researcher can do is to quantify the observations of earlier workers.

Schumm (2005, p X.) 


\section{INTRODUCTION}

This paper is our attempt to synthesize a portion of the vast literature concerning the effects of landscape evolution on channel changes in gravel-bed rivers. More precisely, we try to understand how changes in the boundary conditions of an alluvial plain lead to channel metamorphosis as defined by Schumm in 1969 between two end-member patterns or rivers: highly sinuous meandering and braided.

To proceed we consider the problem in its simplest form: two end-member channel patterns, highly sinuous meandering and braided, and their respective landscapes. We try to understand what changes in boundary conditions lead to a sustainable change in channel pattern. This fundamental question can be broken into three subquestions : (1) Independently of why these different patterns exist, how can one distinguish between the two end-member channel patterns and can the distinction be done quantitatively (§3)?, (2) Can one then, after making a clear distinction between these two patterns, quantitatively relate channel metamorphosis to causative changes in boundary conditions ( $\S 4$ and 5)? (3) Which record of this history and dynamics are we able to decipher from the stratigraphic record $(\S 6)$ ? As we will see these questions broadly correspond to the different types of publications we found. But before adressing these questions, we start with a critical look at existing databases as these are the essential evidences on which most of our understanding is based $(\S 2)$.

Given an exponentially growing body of literature, our strategy was to focus on a somewhat narrower yet more attainable goal. As such, our work strictly applies to alluvial channels. For a comprehensive review of mountain streams, readers are referred to the benchmark works of Montgomery and Buffington (1997) and Wohl (2000). This focus has resulted in us not considering the effect of dead wood channel morphology that has an essential influence on mountain streams. For a review of the role of dead wood in rivers, the reader is referred to Gurnell et al. (2002) and Montgomery et al. (2003). Eventually we have restricted ourselves to the study of archetypes hence "pure" meandering and braided streams. As such we have

avoided the confrontation with the literature on wandering rivers. The reader is referred to Church (2006) for a discussion. 


\section{DATA SOURCES}

We first review the main datasets commonly used in the literature. We looked for datasets containing at least information on dependant and independent variables such as discharge, valley slope and grain size, as well as channel width, depth and sinuosity. Because we do not consider time as a parameter of the problem, we assume that, for a given set of data, fluid discharge, valley slope, grainsize and, when available, sediment transport are independent variables. In contrast, we regard width, depth and sinuosity (linked to channel slope) as dependent variables.

In this section we discuss the databases available to us. First, we explain how we filtered these datasets to extract information concerning gravel-bed streams. Then, we analyze the resulting datasets and discuss their advantages and disadvantages. We point out problems and identify needs for future research and data acquisition.

\subsection{Existing databases and selection criteria}

Hydraulic geometry and stream morphology. The first compendium on river morphology is that of Church and Rood (1983). It contains 500 records in total and the authors made a commendable effort to describe individual data acquisition. 35 single thread streams have both a gravel-bed $\left(D_{50} \geq 2 \mathrm{~mm}\right)$, high $(\geq 1.3)$ sinuosity, and sufficient information on discharge, slope, width and depth. Only 6 reaches are explicitly referred to as braided and gravel-bed.

More recently, van den Berg (1995) published a complementary database devoted to the study of meandering versus braiding streams and contains 227 records. After filtering, 53 complete records concern gravel-bed meandering streams with a high $(\geq 1.3)$ sinuosity and 24 describe gravel-bed braided streams. Van den Berg's compendium contains less information than that of Church and Rood (1983), but it is more recent and therefore contains information acquired after 1983. A small overlap exists between the two databases; however, this remains marginal.

Finally, once both databases are merged and filtered to fit our needs, we end up with a composite dataset of 88 highly sinuous meandering gravel-bed streams and 30 gravel-bed braided streams. This composite dataset will hereafter be referred to as the CRV dataset (data extracted from Church and Rood's and van den Berg's compendia).

Parker and colleagues's (2007) and Osterkamp and Hedman's (1982) compendium are useful when considering the gravel-bed river regime. No information on sinuosity or vegetation was included because the authors did not address this point in their articles and reports. The channel pattern is not mentioned, however the authors noted whether the streams have a single channel or a single thread.

sediment transport Brownlie's (1981a) compendium is not suitable for the problems addressed here. Only 82 concern gravel-bed streams. and no information on river morphology is provided. Few field studies compensate for this. Most published and available datasets 
concern measurements made at a specific section in order to study bedload transport dynamics (Ashworth et al., 1992; Andrews, 1994; Liu et al., 2008; Meunier et al., 2006; Reid et al., 1995) and Milhous (1973 in Brownlie, 1981b). They either do not provide information on the hydraulic geometry and channel planform or they do not make a mass balance calculation that would enable the establishment of annual flux values for bedload to the channel. Very few studies record both a survey of flow and sediment transport over several flow seasons, provide an analysis of channel morphology and make their data available (see King, 2004; Piégay et al., 2004; Ryan and Emmett, 2002).Among these the recent compilation for streams in Idaho provided by King (2004) proves invaluable because it is at present the only database that together provides classical bankfull geometries and bedload fluxes

Vegetation. We used Hey and Thorne's (1986) and Andrews's (1984) databases to examine the effects of vegetation on channel pattern, a topic of much interest today. More than 20 years later, they still remain the best source of information on the relationships between river patterns and vegetation. We complemented these datasets with Huang and Nanson's (1997) dataset on Australian rivers and Rowntree and Dollar's (1999) dataset on the Bell River in South Africa.

Ancient systems. Finally, we searched for databases containing similar information to those available for modern day rivers (i.e., channel pattern, width, depth and sinuosity, as well as discharge, slope, grain size, sediment transport and vegetation cover) for ancient streams. Many studies have carried out quantitative reconstructions of ancient rivers from their deposits. Several attempts to synthesize the data produced by these works also exist for sand-bed streams (e.g, Leeder, 1973; Ethridge and Schumm, 1978). Quantitative studies for gravel-rivers are not so common and they still need to be harmonized and synthesized (see $\S 6.2)$.

\subsection{Tools}

We use simple tools for the analyses in this paper. The use of complex statistical analyses, or fitting techniques, is inappropriate for two reasons: (1) the datasets are small, and (2) the scatter in the data. When needed, we use the ordinary least squares fit and linear approximations. We use cumulative distribution functions (CDFs) instead of probability distribution functions (PDFs) to compare distributions visually. CDFs are complemented by quantile-quantile plots (Q-Q plots). Q-Q plots compare the quantiles of two distributions to check whether they are equivalent or significantly different. For instance, to compare the distribution of discharges for a given set of meandering and braided streams, we first

calculate the discrete CDFs of the discharges for the two stream types. Each quantile $Q_{5}, Q_{10}, \ldots, Q_{i}, \ldots Q_{95}, Q_{100}$ is then compared individually in a plot $\left(Q_{i, \text { meander }}, Q_{i, \text { braided }}\right)$. If the distributions are equal, the plotted points are aligned on the $y=x$ line. If the distributions are similar but differ in some of their parameters, the points align on another line. If the distributions differ, the points may no longer plot on a line. This is a fast and simple 


\begin{tabular}{llllll}
\hline Source & NR & NGB & Braided & Sin.-Mean. & Highly sinuous $(>1.3)$ \\
\hline Church and Rood (1983) & 500 & 430 & $6^{+}(0)$ & 74 & $35(10)$ \\
van den Berg (1995) & 227 & 164 & $24(22)$ & 53 & $53(22)$ \\
Parker et al. (2007) & 181 & 181 & NA & NA & NA \\
Osterkamp and Hedman (1982) & 454 & 123 & NA & NA & NA \\
Andrews (1984) & 24 & 24 & 0 & & \\
Hey and Thorne (1986) & 62 & 62 & 0 & 56 & 14 \\
Huang and Nanson (1997) & 30 & & 0 & NA & NA \\
Rowntree and Dollar (1996) & 10 & 10 & 0 & 10 & 2 \\
Brownlie (1981a) & 1764 & 82 & NA & NA & NA \\
King (2004) & 34 & 34 & NA & NA & NA \\
\hline
\end{tabular}

Table 1: Data sources for gravel-bed streams. Meandering and braided streams were counted when information on discharge, slope, grain size, width, depth and sinuosity was given. NR: Number of records. NGB: Number of gravel-bed streams . + No information on sinuosity is given for gravel-bed braided streams in Church and Rood's compendium. Numbers in parentheses indicate streams with a bankfull discharge equal to or greater than $100 \mathrm{~m}^{3} / \mathrm{s}$. See text for explanations.

way to visually scan the available databases to find datasets with independent parameter distributions as similar as possible.

\subsection{Relevance of existing databases}

It is important to identify deficiencies in any given database, first to delineate goals for future field surveys, and second because these limitations may limit the generalizations that can be made from the analysis proposed.

Later, we will discuss what is commonly called hydraulic geometry and regime relationships. A river regime, or grade, relies on adjusting the dependant variables to a set of three independent parameters: grain size of the particles composing the bed, water discharge, and sediment flux. Figure 1 shows the CDF curves and Q-Q plots for the median grain size of the meandering and braided rivers in the CRV dataset. It shows that grain size distributions for braided and meandering streams are similar and to a first order, they follow the same distribution function. However, the range in grain size is limited, as $90 \%$ of the streams have $D_{50}$ above $1 \mathrm{~cm}$. Hence, fine gravel bed streams are not present. Therefore, it can be argued that the studies and analysis used here do not apply to rivers with beds composed of fine gravel.

Figure 2 shows the same CDFs and Q-Q plots for the discharges with quite different results. The discharge distributions do not collapse on the $y=x$ line . First, this means that the statistical distributions of discharges between meandering and braided streams recorded in Church and Rood's and van den Berg's databases are significantly different. Second, the CDFs show a difference of an order of magnitude in the median discharge of the 

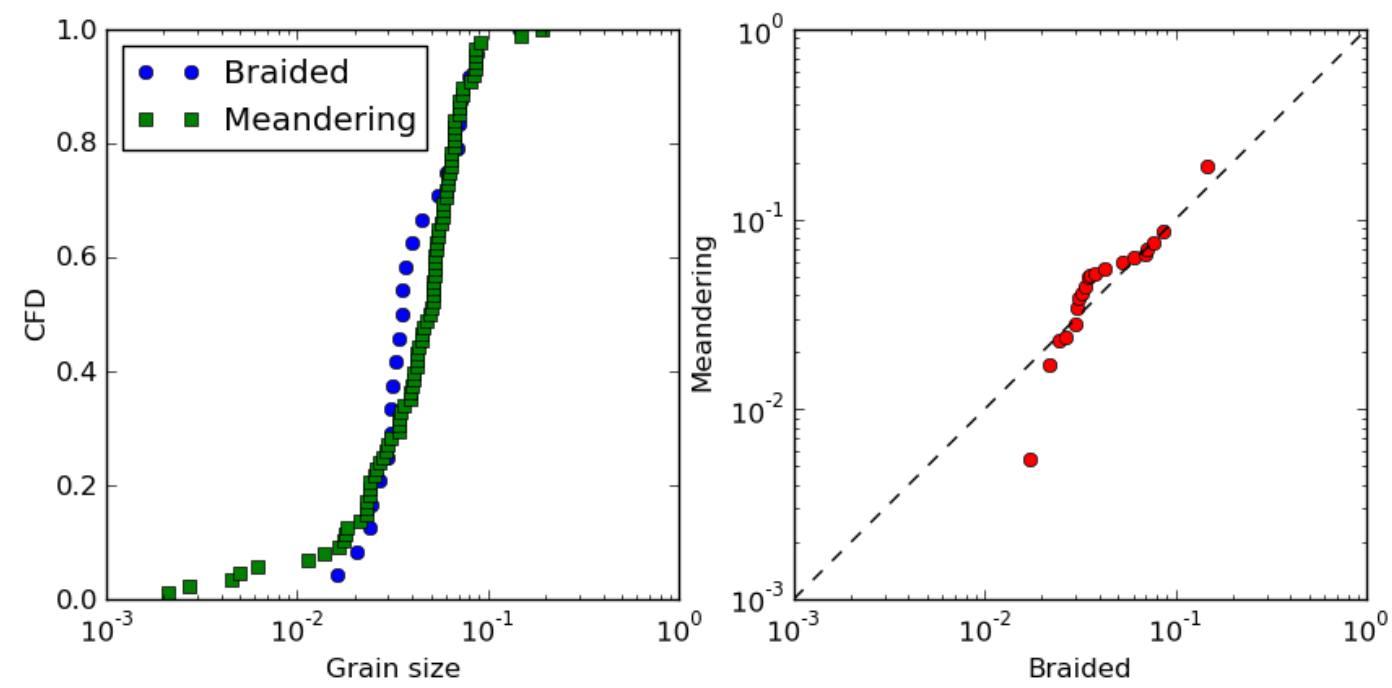

Figure 1: Left: CDFs of the median grain sizes in the existing data on gravel-bed meandering (52 reaches) and (30 reaches) braided streams. Right: Q-Q plot of the same distributions.

distributions. This means that meandering streams in the CSV dataset are "small" rivers, whereas braided streams are much "larger" rivers (in the discharge sense). The issue here is simple: it is impossible to tell whether gravel-bed meandering streams are, on average, smaller streams than braided ones, or if the distributions are biased because the existing databases do not reflect the natural ranges of discharges of both highly sinuous meandering and braided streams.

Strictly speaking, if we wish to compare channel patterns for stream datasets that statistically have the same distribution for both median grain size and discharge, we end up with 32 meandering and 22 braided reaches with a discharge above $100 \mathrm{~m}^{3} / \mathrm{s}$ (numbers in parentheses in Table 1). Figures 3 and 4 show the CDFs for the median grain size and discharge of these streams. The grain size distributions remain similar and the discharge distributions are much closer to the $y=x$ line. At least, they follow a linear relationship. This is in no way perfect, but it approximately fulfills an important criterion: the independent parameters are not equal but are of the same order of magnitude. Thus, the patterns we observe are not biased by the nature of the dataset. We will refer to this stream subdataset (gravel-bed highly meandering and braided streams with discharge above $100 \mathrm{~m}^{3} / \mathrm{s}$ extracted from the Church and Rood and Van Den Berg compendia) as the $\mathrm{CRV}_{100}$ dataset.

Finally, we calculated the CDFs and Q-Q plot of valley slopes for both meandering and braided streams in the $\mathrm{CRV}_{100}$ dataset when the valley slope was available, either directly or through channel slope and sinuosity (Figure 5). The two distributions are not the same but they probably reflect the same statistical distribution with different parameters because braided streams flow on higher slopes than meandering ones. 

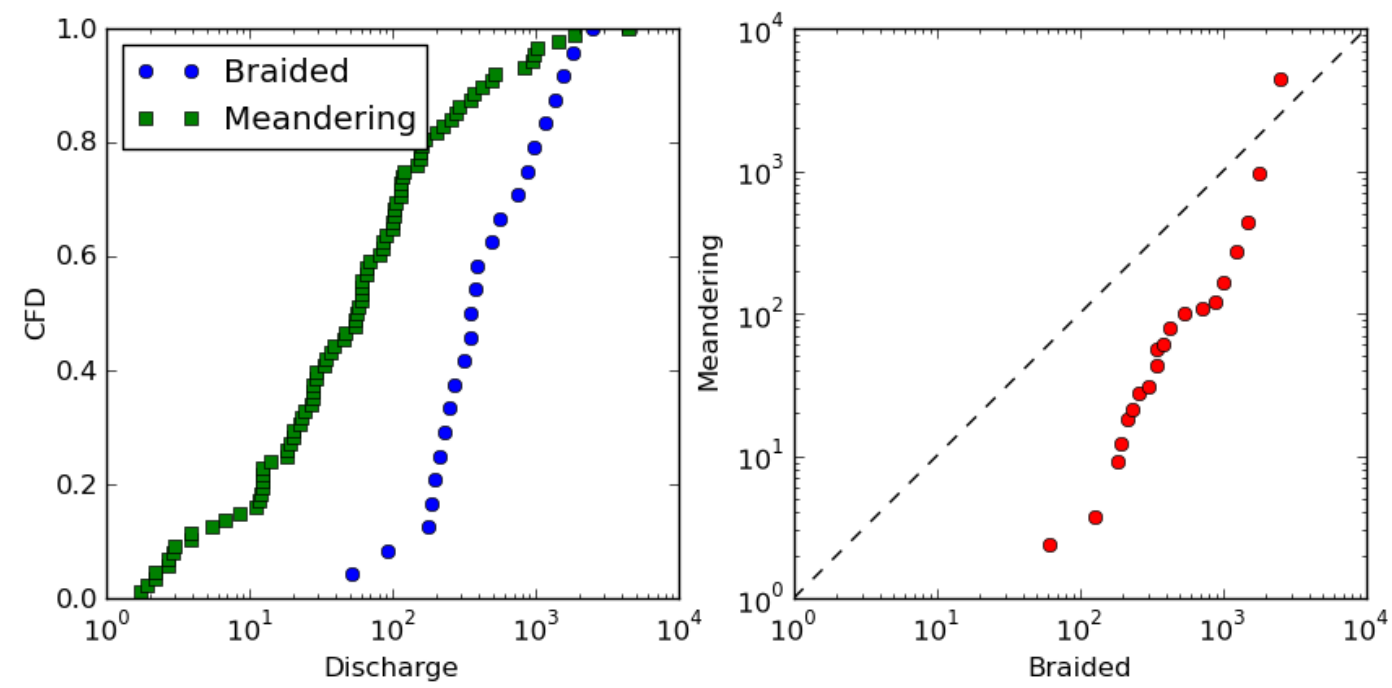

Figure 2: Left: CDFs of discharges in the existing data on gravel-bed meandering (52 reaches) and braided (30 reaches) streams. Right: Q-Q plot of the same distributions.

If a conclusion can be drawn from this analysis, it is that further surveys should concentrate on large gravel-bed meandering streams and small gravel-bed braided streams to expand existing databases. Furthermore, streams with fine gravel beds should be searched for because they bridge the gap between the more common "gravel-bed" and "sand-bed" rivers. Finally, sediment fluxes, and especially bedload, are unknown for most of the rivers in the databases. Along with morphologic parameters, sediment transport and especially bedload (in order to derive long term fluxes) should be surveyed extensively. 

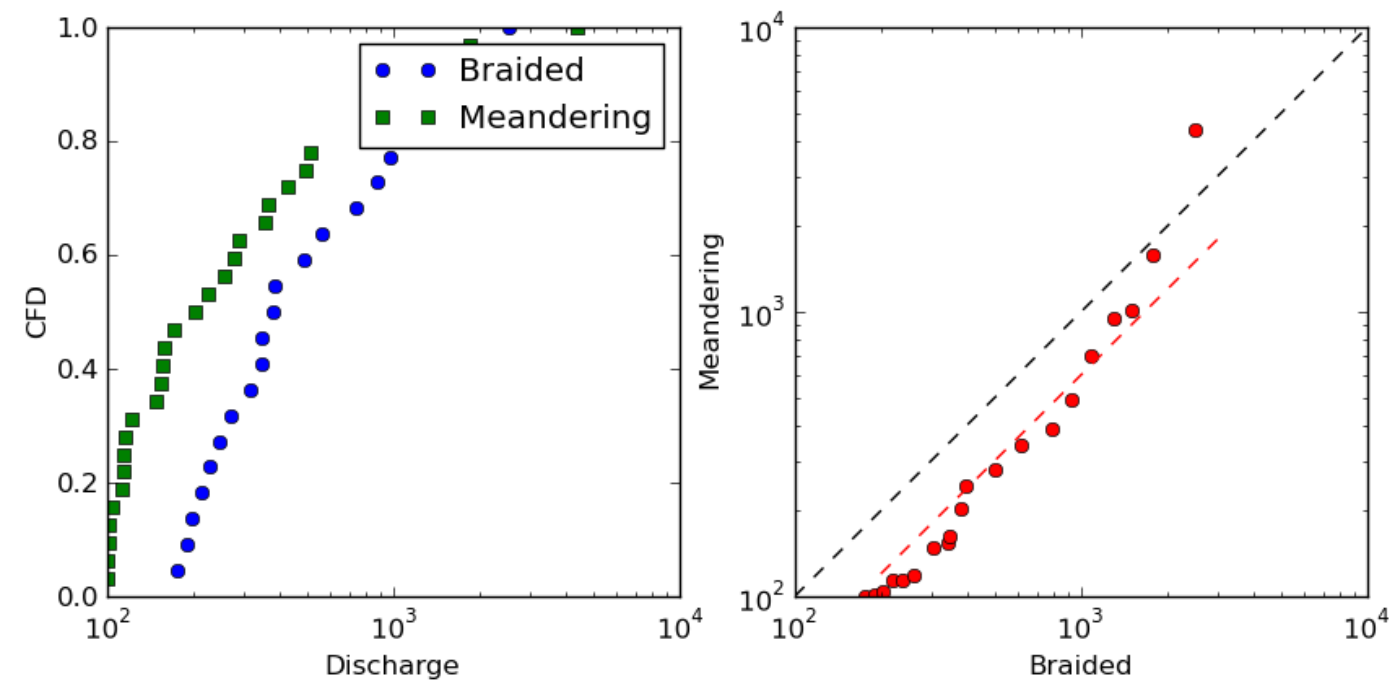

Figure 3: Left: CDFs of discharges in the existing data on gravel-bed meandering (32 reaches) and braided (22 reaches) streams with a discharge above $100 \mathrm{~m}^{3} / \mathrm{s}$. Right: Q-Q plot of the same distributions.
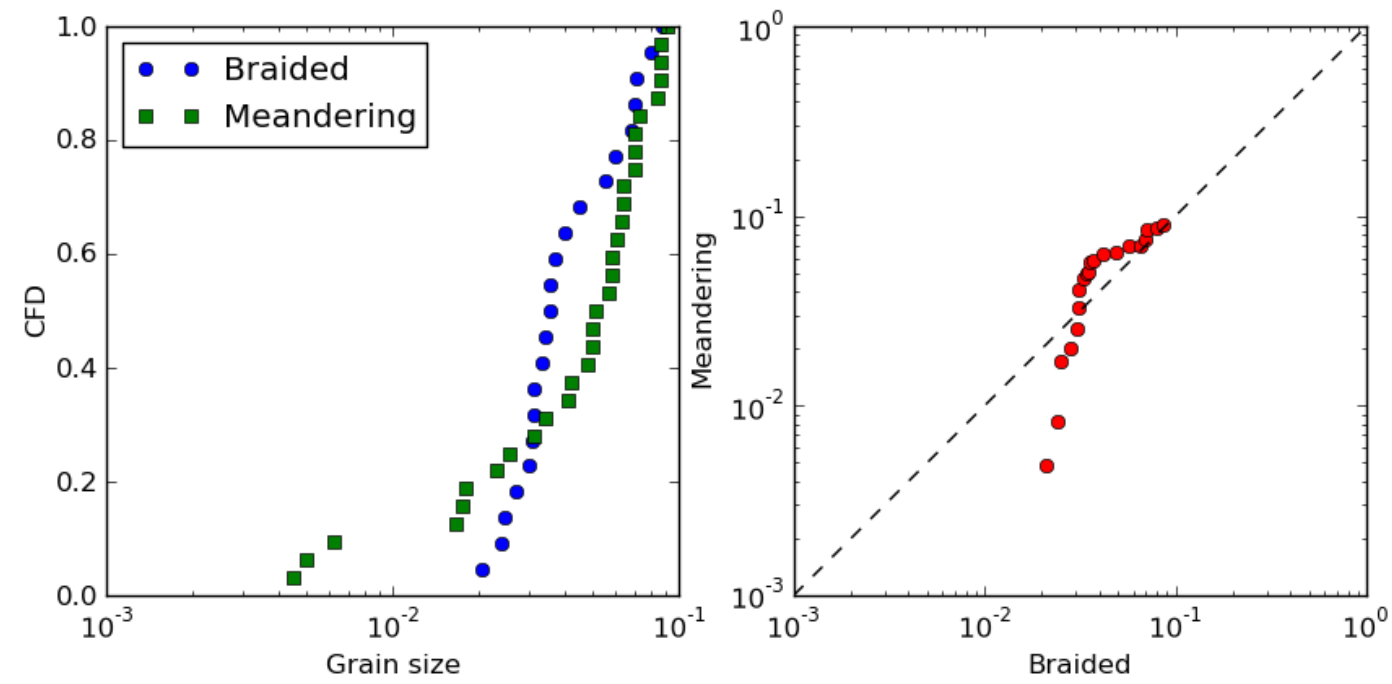

Figure 4: Left: CDFs of the grain size in the existing data on gravel-bed meandering (32 reaches) and braided (22 reaches) streams with a discharge above $100 \mathrm{~m}^{3} / \mathrm{s}$. Right: Q-Q plot of the same distributions. 

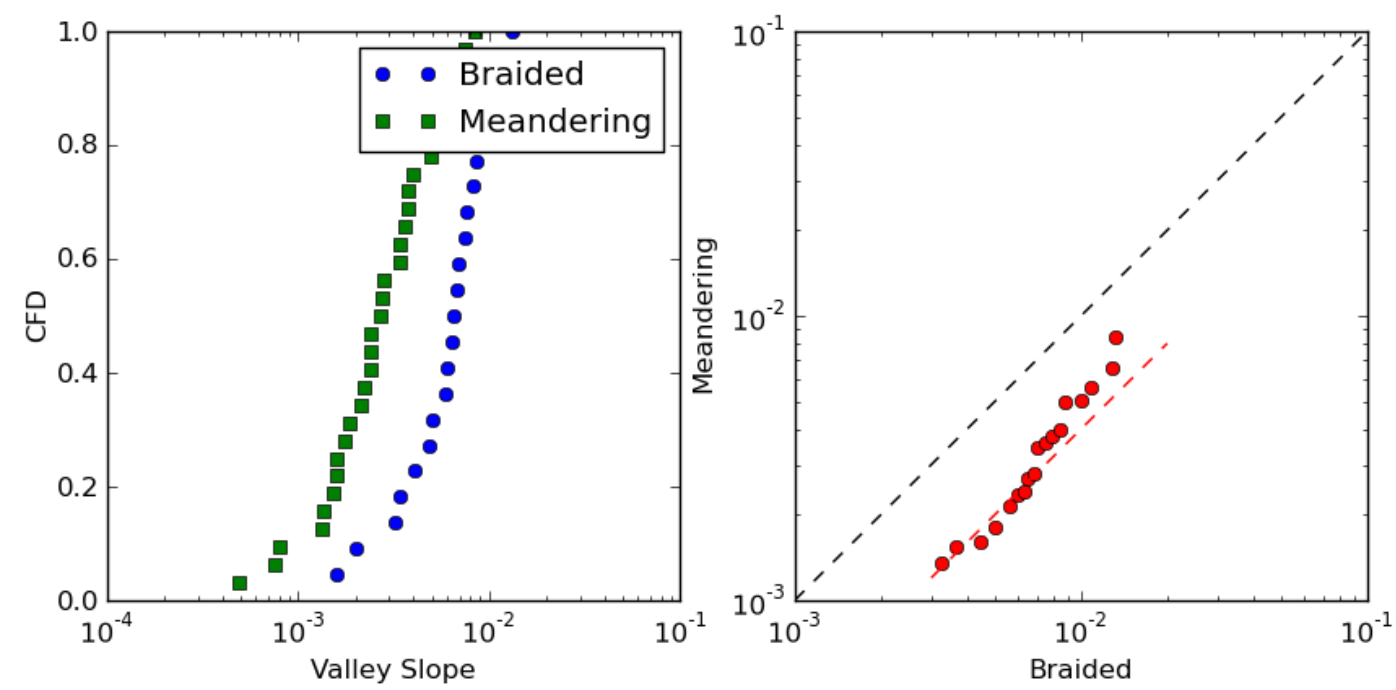

Figure 5: Left: CDFs of the valley slope in the existing data on gravel-bed meandering (32 reaches) and braided (22 reaches) streams with a discharge above $100 \mathrm{~m}^{3} / \mathrm{s}$. Right: Q-Q plot of the same distributions. 

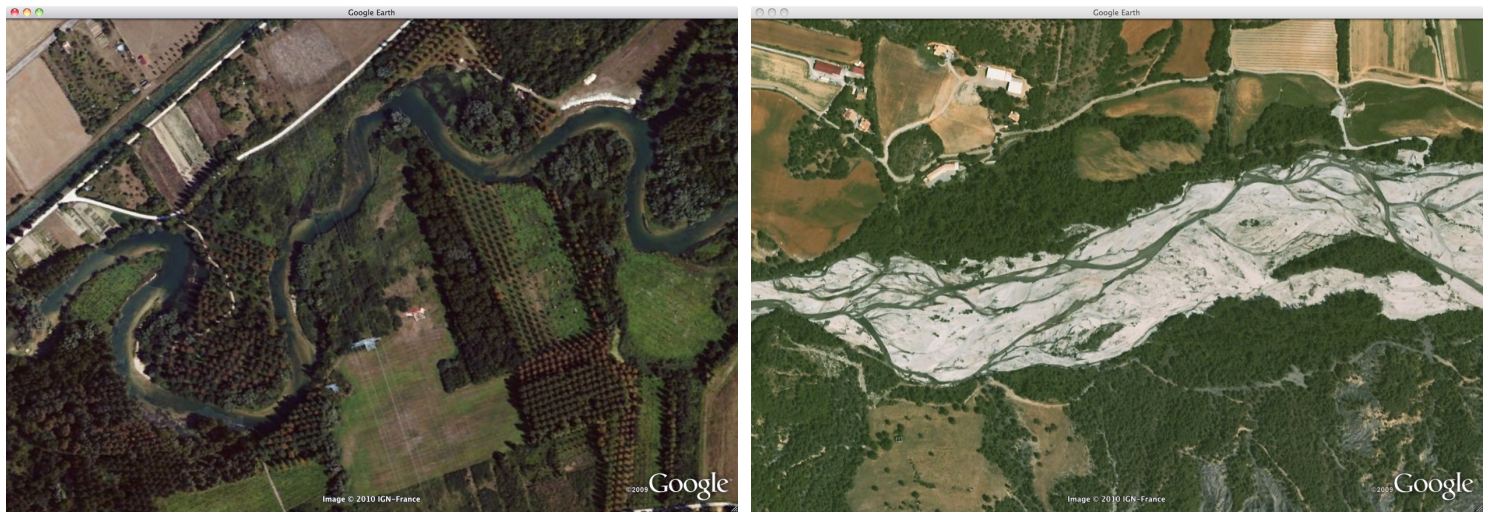

Figure 6: Typical examples of meandering and braided gravel bed streams. Meandering: Seine river near Méry-sur-Seine, France; braided: Bléone river in the French Alps near Dignes-les-Bains. The width of flow is $20-30 \mathrm{~m}$ in both cases. Images from Google earth.

\section{DEFINING MEANDERING AND BRAIDED STREAMS}

\subsection{Planform definition}

Channel and threads In this article, a channel is considered as the entire area where flow and sediment transport occurs on an alluvial valley, fan or plain. A channel is separated from a potential adjacent flood plain by banks, where flow and sediment transport occur more episodically during the highest flow stages. These banks correspond to somewhat sharp topographic steps. A river channel may consist of flow organized in a single thread or multiple threads within a single channel. A meandering stream is composed of one channel that has one active thread, whereas a braided stream corresponds to one channel with flow divided among several threads. Within and between these active threads, bars or temporary islands usually exist, migrate, and are modified as the threads wander across the channel. These bedforms are part of the channel (Schumm, 1977, 2005). This definition corresponds to the framework of mechanical stability analyses (Parker, 1976).

Sinuosity As in previous studies (e.g., Leopold and Wolman, 1957; Brice, 1975; Rust, 1978a; Friend and Sinha, 1993), sinuosity is defined here as the ratio of the channel length measured along the stream between two points to the shortest distance between the same two points. Using this definition, a straight channel would have a sinuosity of one. Conversely, meandering channels, which are tortuous channels, have sinuosities greater than one. Meandering streams are highly sinuous when their sinuosity is greater than 1.3 (Schumm, 1977). Individual braided threads may be locally sinuous, but the braided channel as a whole often has a low sinuosity close to 1 . This can be seen in the CDFs and QQplots of sinuosities for meandering and braided streams for the $\mathrm{CVR}_{100}$ dataset. 

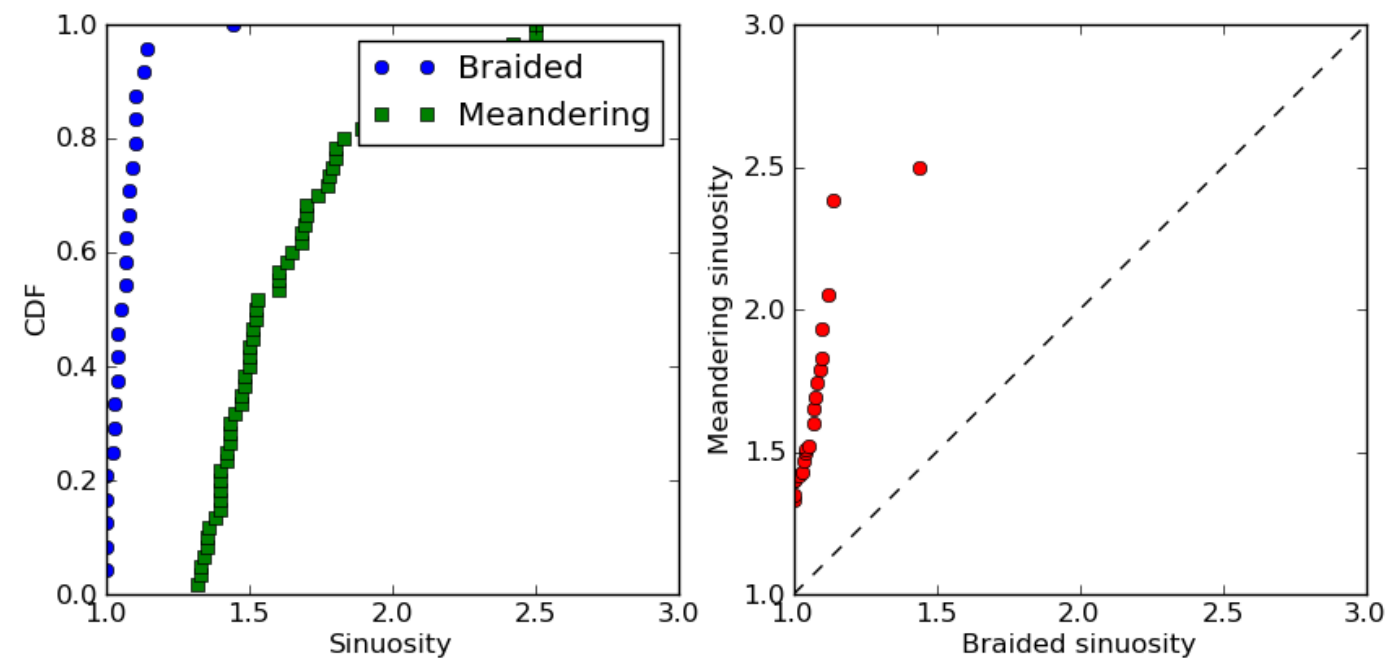

Figure 7: Left: CDFs of the sinuosities for the meandering and braided streams from the $\mathrm{CVR}_{100}$ dataset. Right: QQplot of the same distributions.

Type of sediment load In the sixties and early seventies, classifications associating channel patterns with sediment transport types were developed based on the study of sand-bed streams (Schumm, 1977, 1987, 2005; Church, 2006). In these classifications, braided streams are defined as being predominantly bedload, whereas meandering streams are mostly mixedload or suspended-load. Highly sinuous meandering streams were always associated with suspended load (Schumm, 1977). These classifications do not hold for meandering in the case of gravel-bed rivers.

The relative contributions of suspended and bed material can be characterized using the dimensionless Rouse number (Vanoni, 1940; Garcia, 2008):

$$
R o=\frac{v_{s}}{\kappa u_{*}}=\frac{v_{s}}{\kappa \sqrt{\tau_{b} / \rho}}
$$

where $u_{*}=\sqrt{\tau_{b} / \rho}$ is the shear velocity, $\tau_{b}$ the shear stress exerted on the bed by the flow, $v_{s}$ the settling velocity of the sediment composing the bed, and $\kappa=0.4$ the von Karman constant. For a Rouse number above 2, 90\% of the sediments are transported in the lower $10 \%$ of the flow (Vanoni, 1940) and therefore move as bedload.

We calculated Rouse numbers for the rivers in the $\mathrm{CVR}_{100}$ dataset. The values are always much larger than 2. This means that the median-size material comprising gravelbed streambeds moves almost exclusively as bedload. Although a distinction can be made between meandering and braided stream distributions, there is no clear difference in the material transport mode. Therefore, the distinction between bed, mixed and suspended load originally proposed by Schumm (1977) for sand-bed streams does not apply when considering 
the median grain size of gravel-bed streams.

Aspect ratio Lane (1937) was probably the first to cite the importance of the aspect ratio from an engineering point of view. Yet its potential importance as a parameter relevant to characterizing stream morphology was likely cited first by Schumm (1960), who later used it as a fundamental criteria for his stream morphology classification (Schumm, 1963, 1977). It has been widely used since then (e.g., Schumm, 2005; Church, 2006), although a physical basis for its importance was only proposed in the late seventies by Parker (1976). Based on a linear stability analysis of flow and sediment transport equations, Parker (1976) demonstrated that the aspect ratio was as a first order criterion governing channel morphology. Yet, despite this significant advance, hydraulic geometry studies have focused on characterizing individual channel width and depth rather than their ratio and focused on individual dependant variables rather than their dimensionless ratio. The quantitative importance of the aspect ratio was only re-acknowledged less than ten years ago by Millar (2000) and others from the University of British Columbia.
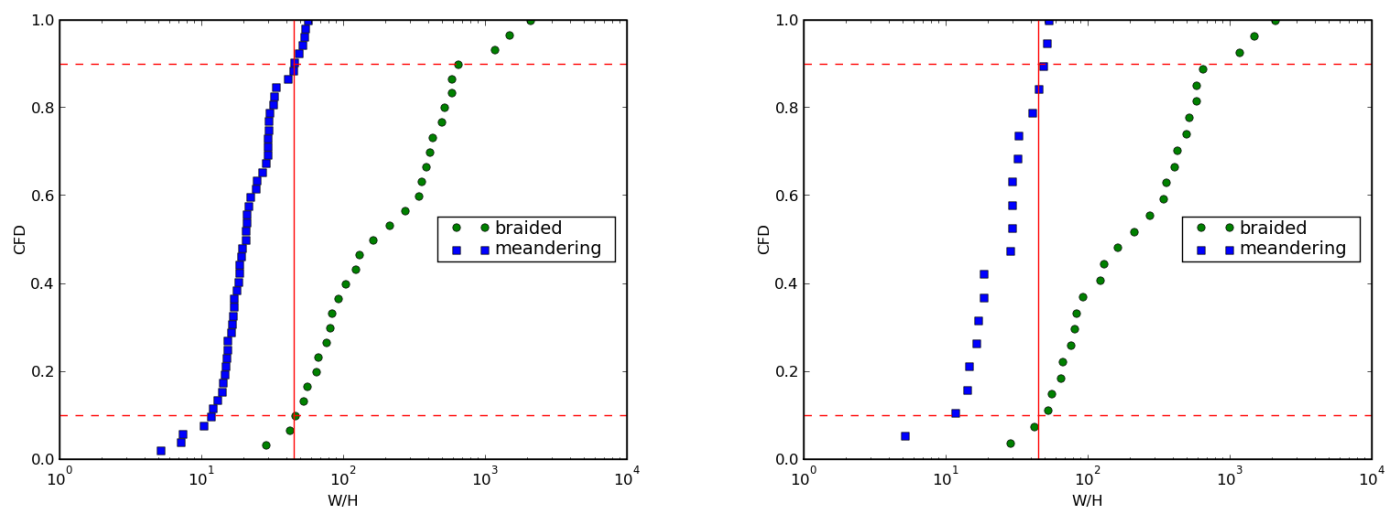

Figure 8: CDFs of the aspect ratios for gravel-bed meandering and braided streams from the (left) $\mathrm{CRV}$ dataset, and (right) $\mathrm{CVR}_{100}$ subdataset of reaches with similar discharges and grain sizes. Dashed lines indicate 10 and $90^{t h}$ percentiles respectively. The vertical line marks the threshold at 45 .

Figure 8 shows the CDFs of the stream aspect ratios for the CRV and CVR 100 datasets. They portray the exact same scenario and confirm both Schumm's and Parker's conclusion that meandering and braided streams statistically have very different aspect ratios. Ninety percent of highly sinuous meandering streams from the $\mathrm{CVR}_{100}$ dataset have aspect ratios less than 45 whereas $90 \%$ of braided streams have aspect ratios above 45 . This threshold corresponds closely to the value of 40 proposed by Schumm (Schumm, 1968a, p. 40 table 5). Thus to the first order, aspect ratios of streams seem to be an excellent discriminator between meandering and braided planforms. 


\subsection{The choice of criteria for metamorphosis in channel patterns}

In order to quantify the conditions which induce changes in channel patterns, we must first define objective criteria for these changes. These criteria have been the subject of endless debate since the work of Leopold and Wolman (1957). The criterion they proposed is a threshold slope set by some power function of the discharge. The idea being that Meandering streams have slopes less than or equal to the threshold, while braided slopes are above the threshold - . This criterion was further developed by Lane (1957) in order to explain observed discrepancies for the Chippewa River Similar discrepencies were alsodiscussed by Simpson and Smith (2001). Ultimately, the criterion developed by Leopold and Wolman (1957) and refined by Lane (1957) suggests that slope is an essential parameter for differentiating braiding and meandering streams. A discussion of this approach and which sheds light on its limitations can be found in Carson (1984), van den Berg (1995) and Lewin and Brewer (2001). The main point being that it is basically empirical and it has the drawback that it mixes dependent and independent variables.

Such empirical studies will probably continue to explore the range of possible correlations as databases grow, however, for our purposes, we will use the criterion of Parker (1976) which is the first simple yet physically grounded criterion to come along. Its definition is worthy of discussion because we feel it has been misused. Using a given set of values for discharge, slope, sediment transport, and width for a rectangular channel with non erodible banks, Parker performed a linear stability analysis of momentum and mass balance equations for both flow and sediment transport. The derived dispersion equation shows that for a given set of conditions, local instabilities develop on the bed in the form of patterns called braids, which are composed of rows of alternating bars. The number of braids $m$ dictates the tendency for the stream to evolve into a meandering $(m=1)$ or braided $(m \geq 2)$ pattern. Hence, for a given set of boundary conditions and channel size, the criterion Parker (1976) developed analyzes how the internal (autogenic) instability of the system leads to its evolution into either a meandering or braided pattern. Parker proposes that for meandering or braiding to occur, sediment transport must, to the first order, be non zero, and that the number of braids (rows of bars) is proportional to a dimensionless ratio $\epsilon^{*}$ defined as:

$$
\epsilon^{*}=\frac{S_{c} W}{\pi \mathbf{F} H}
$$

where $S_{c}$ is the channel-bed slope, $W$ the width, $H$ the flow depth and $\mathbf{F}$ the flow Froude number. If $\epsilon^{*}<<1$, then $m=1$ and the river develops alternate bars and hence, evolves into a meandering pattern. If $\epsilon^{*}>1, m>1$, then the river develops several rows of alternate bars and evolves into a braided pattern. For $\epsilon^{*} \simeq 1$, both patterns can coexist. Parker dropped the $\pi$ value because it is of order one and thus the river braids if $S_{c} / \mathbf{F}>>H / W$ and the river meanders if $S_{c} / \mathbf{F}<<H / W$. Figure 9 analyses the criterion developed by Parker (1976) applied to the $\mathrm{CVR}_{100}$ dataset, showing that the equation works quite well. In a strict sense, all the rivers comply with the criterion (dotted lines in Figure 9. It also works quite well broadly, as there are few "unpredicted" meandering and braided streams.

As such, we can conclude that for a given characteristic discharge and channel width, assuming the bedload is non zero, natural (autogenic) instabilities will develop, pushing 


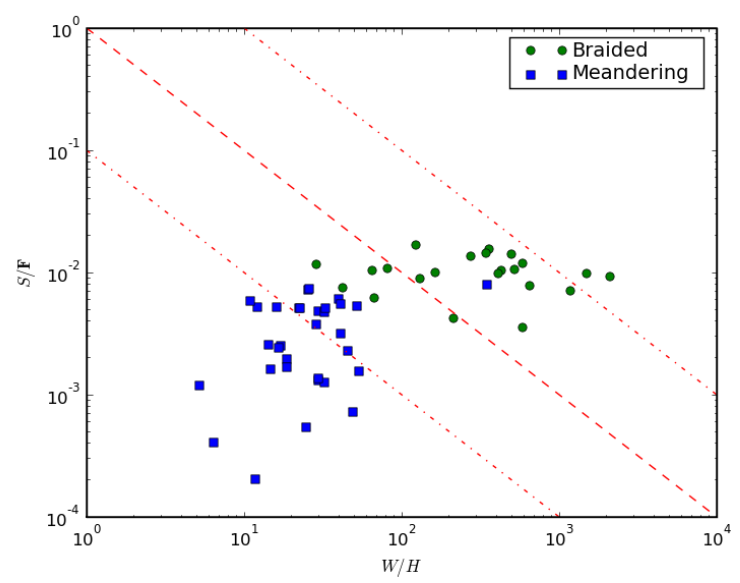

Figure 9: Application of the criterion defined by Parker (1976) to the CRV dataset. Dashed lines correspond to $S_{c} / \mathbf{F}=H / W$. Dotted lines correspond to $S_{c} / \mathbf{F}=0.1 H / W$ and $S_{c} / \mathbf{F}=$ $10 H / W$, respectively.

the evolution of a given alluvial stream towards an end member pattern. This agrees with Schumm's empirical finding and classifications and it enables the independent assessment of the external (allogenic) factors controlling the important variables of an alluvial stream $\left(S_{c} / \mathbf{F r}, W / H\right)$. Parker's criteria, developed more than thirty years ago, therefore seems to be a highly adequate approach to study the consequences of landscape changes on channel metamorphosis.

To summarize: both observations and stability analysis lead to the conclusion that the planform dynamic of any thread and bedform is related to the system's internal dynamics and therefore is autogenic. In conrast, thread numbers are controlled by boundary condtions, that is to say allogenic factors.. 


\section{Hydraulic geometry and the respective influence of water and sediment inputs}

\subsection{Hydraulic geometry}

The concept of an equilibrium channel with regard to sediment fluxes was later introduced by Mackin (1948) and defined as a graded stream (i.e., a stream whose slope is adjusted to transport the sediment input load given an existing water flux and channel form). As pointed out by Mackin, a stable regime channel is at grade. However, the converse is not necessarily true, as the most important feature of a graded stream is its ability to carry the imposed load over long time scales, irrespective of the channel form. Knowing these differences, we will use the term equilibrium channel, regime channel or graded channel in the most restrictive sense: a stream that has both a geometrically stable section and is at grade. The channel, therefore, is defined by its hydraulic geometry.

Although concerns about hydraulic geometry date back to the work of engineers of the British Empire in the late 19th century (work reported in Lane, 1937), hydraulic geometry studies likely started with the first series of relationships proposed by Leopold and Maddock (1953). They showed that, to the first order, certain channel geometry measurements (width, depth, velocity, slope) scale as power law functions of characteristic discharge, as follows:

$$
A=a_{A} Q^{b_{A}}
$$

where $A$ can be any dependant variable of the stream (width $W$, depth $H$, flow velocity $U$ or slope $S_{c}$ ) and $Q$ is the fluid discharge. The most intriguing feature of these scaling relationships is that the $b_{A}$ exponents show remarkable constancy.

By far, the most important of these relationships is that of channel width, which turns out to scale approximately as the square root of the discharge, hence:

$$
W \propto Q^{1 / 2}
$$

It is important because we are still unable to generally close one of the most important problems in fluvial geomorphology: what sets a river's width?

Considered in more detail, hydraulic geometry equations define the functional dependency of a set of dependant variables that adjust to a set of independent variables constituting the system's boundary conditions, as follows:

$$
W, H, S_{c}=\Phi\left(Q, Q_{b}, D, g, \rho, \rho_{s}\right)
$$

where $Q_{b}$ is the bedload flux, $D$ some characteristic grain sizes and $g, \rho, \rho_{s}$ is the gravity acceleration, water density and sediment density, respectively. As $Q_{b}$ is usually not known, it has been argued (e.g., Yalin and da Silva, 2001) that equation (5) could be, to the first order, reduced to:

$$
W, H, S_{c}=\Phi\left(Q, D, g, \rho, \rho_{s}\right)
$$


In order to close the problem for the very simple case of a straight immobile channel, a reliable physical description of the shear stress distribution across any natural channel section is needed (Parker, 1978; Knight, 1981; Diplas, 1990; Shiono and Knight, 1991; Wilcock, 1996; Vigilar and Diplas, 1997; Kean and Smith, 2005). Once this is defined, it becomes possible to ask under what flow conditions the river banks and channel will remain stable. However, just having a stable bank is insufficient because for a given discharge and grain size, there exists a range of solutions in which the bank is stable, yet only one is selected.

Consequently, predicting hydraulic geometry has been a matter of endless debate. Several researchers have proposed minimizing or maximizing one of the problem's variables. It has long been acknowledged (Gilbert was probably first to note it) that some of the problem's dependant variables present optimums. It was then argued that the existence of these potential optimum conditions is the missing condition needed to close the problem (for a review, see Yalin and da Silva, 2001; Eaton and Millar, 2004; Millar, 2005). Indeed, the maximization or minimization of any of the dependant variables makes it possible to select one solution from a set of possible solutions. From a practical point of view, this technique is advantageous as it proposes some simple solutions to the problem.

In an opposite approach, others have considered the minimum number of constraints and equations necessary to define hydraulic geometry relationships (Parker, 1978; Parker et al., 2007). In this case, a physical explanation is found a posteriori for the constraints for which no mechanistic derivation exists.

As often observed in the natural sciences, it is interesting to note that the conclusions are relatively similar, regardless of the method employed. One of the most important conclusions derived from studying the transverse distribution of shear stresses is that an equilibrium stream must have a relatively low maximum shear stress, which is only slightly above critical. Yalin and da Silva (2001) arrive at a seemingly more provocative, yet very similar, conclusion. They conclude that an equilibrium gravel-bed stream is one where the sediment composing the bed is at the threshold of motion. Note that this conclusion is derived for the theoretical case, with no sediment input, whereas the derivations of Parker (1978) and others allow for some bedload transport.

The regime equations proposed by Yalin and da Silva (2001) are interesting because they are provocative. At the very least, they are interesting because, as quoted in $\S 2$, no database exists that contains information on regime morphology and sediment flux. Hence, Yalin and da Silva (2001) conjecture that sediment flux is not necessary because either there is none or it is sufficiently small enough that it can be neglected to the first order. Figure 10 shows that this conjecture seems to hold and at least is not contradictory with Parker and coauthors's recent analysis. We will therefore use Yalin and da Silva's regime equations as they are relatively simple:

$$
\begin{aligned}
W & =1.42 \sqrt{\frac{Q}{u_{* c r}}} \\
H & =\frac{D^{1 / 7}}{7}\left(\frac{Q}{u_{* c r}}\right)^{3 / 7}
\end{aligned}
$$



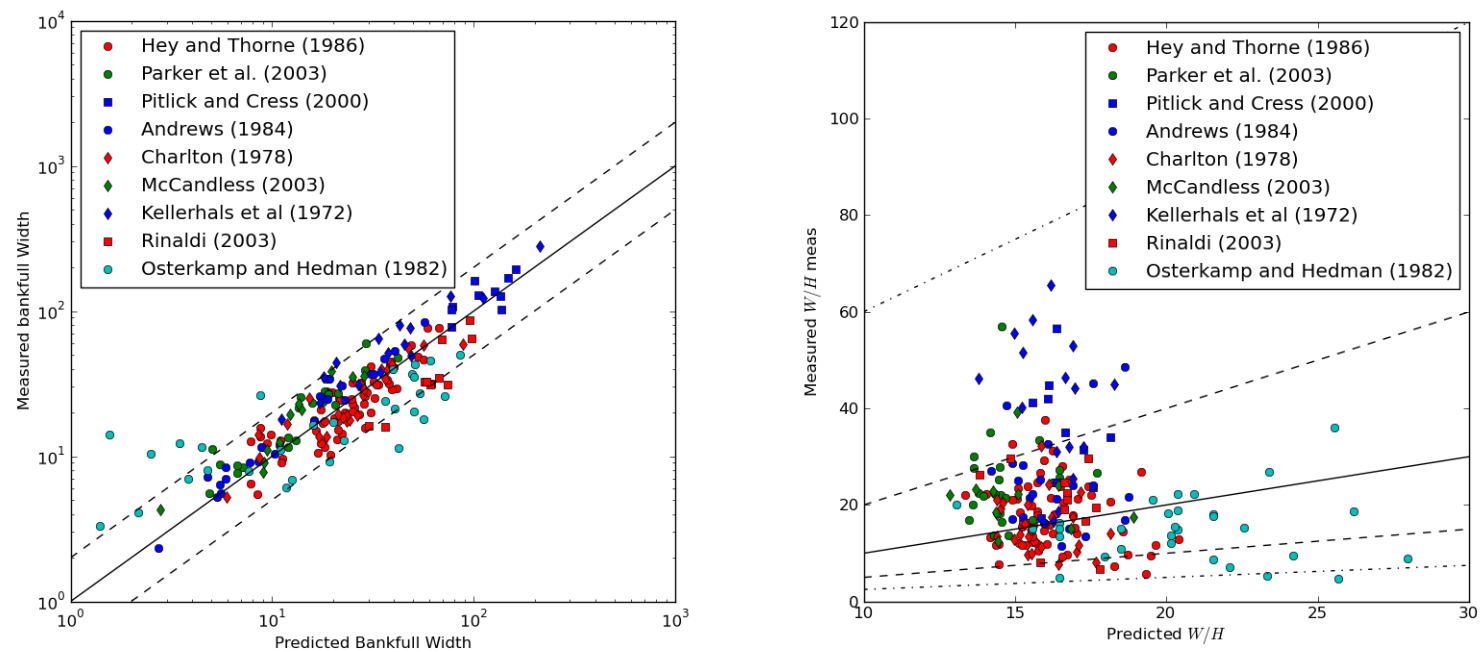

Figure 10: Left: Comparison between measured and predicted bankfull width using Yalin and da Silva (2001)'s regime equation for gravel-bed streams. The black line corresponds to perfect agreement $W_{\text {meas }}=W_{\text {Pred }}$, dashed lines correspond to $W_{\text {meas }}=2 W_{\text {Pred }}$ and $W_{\text {meas }}=0.5 W_{\text {Pred }}$. Right comparison between the measured and predicted aspect ratio using (Yalin and da Silva, 2001)'s regime equation for gravel-bed streams. The black line corresponds to perfect agreement, dashed lines correspond to an agreement within a factor of 2 , the dotted line corresponds to agreement within a factor of 4 .

$$
S_{c}=\frac{u_{* c r}^{2}}{g} \frac{7}{D^{1 / 7}}\left(\frac{u_{* c r}}{Q}\right)^{3 / 7}
$$

Here, $u_{*, c r}$ is the shear velocity corresponding to the inception of motion. For a critical Shield's stress $\theta_{c}=\rho u_{*, c r}^{2} / \Delta \rho g D \sim 0.045$ we then have:

$$
u_{*, c r}=\sqrt{\tau_{c} / \rho} \sim 0.853 \sqrt{D}
$$

Therefore, for a given set of physical parameters (density, gravity, viscosity), dependant variables are solely functions of discharge and some characteristic grain sizes, such as the $D_{50}$ of the bed.

\subsection{The weak influence of discharge}

There has been a large effort to understand the effect of discharge on channel width, depth, and slope (or velocity). Since Leopold and Maddock's (1953) work, many researchers have tried to quantify the variability of exponents in equations like (3) for different settings and boundary conditions (Merigliano, 1997; McCandless and Everett, 2002; McCandless, 2003; Blizard and Wohl, 1998; Wohl, 2004; Huang and Warner, 1995). 
Despite its clear importance as a delineator between braided and single-thread channels, no study has really addressed the problem of the influence of discharge on a stream's aspect ratio. Eaton et al.'s (2004) study is the only one merging a discussion of hydraulic geometry with an analysis of Parker's (1976 stability criterion. Using Parker's criterion, defined from his linear stability analysis, and assuming that at regime, the river planform follows Yalin and da Silva's set of regime equations, we end up with the following equations:

$$
\begin{aligned}
& \frac{W}{H} \simeq 10 D^{-1 / 6} Q^{1 / 14} \\
& \frac{S_{c}}{\mathbf{F r}} \simeq 0.02 D^{1 / 3} Q^{-1 / 7}
\end{aligned}
$$

Figure 10 results from equation (11). It works reasonably well, as most streams fall within a factor of 2 of perfect agreement and all the streams fall within a factor of 4 . The consequences are immediate: given the exponents in equations (11) and (12), discharge fluctuations alone cannot drive a change in the channel planform. A 16,000-fold change in discharge would be needed to change the aspect ratio by a factor of 2 . A reasonable one-fold change in discharge would lead to a 1.18 factor change in the aspect ratio and a 0.71 factor change in friction $\left(S_{c} / \mathbf{F r}\right)$. Hence, the influence on channel pattern stability would remain marginal.

To summarize, it is interesting that one of the most important underlying consequences of river regime studies developed during the past 50 years since Leopold and Maddock's work, is that a change in discharge might not induce a change in the channel pattern from meandering to braided streams or vice versa.

\subsection{The influence of bedload}

Changes in landscape may induce changes in both grain size and amount of sediment delivered to the channel. As can be seen from equations (11) and (12), a one-fold change in grain size will mainly affect the friction term in Parkers' stability analysis by a factor of 2 . This will affect the aspect ratio by a factor of slightly less than 0.7 . Hence, if a change in planform occurs from braided to meandering or vice versa, it probably will not be because of a change in grain size, provided that the stream remains a gravel bed.

One important assumption embedded in the analyses developed by Parker et al. (2007),Schumm (1963),Schumm (1977) and Yalin and da Silva (2001) is that sediment transport in stable gravel bed streams remains small because shear stresses are only slightly above their critical value. Using the $\mathrm{CRV}_{100}$ dataset, we can partially test this assumption and compare the prediction for meandering and braided streams (Figure 11). Most highly sinuous meandering streams plot within a factor of two of the 1:1 correlation line, whereas most braided streams plot largely above this line. Measured widths are much larger than predicted ones. For gravel bed braided streams, the assumption of zero or marginal movement breaks down. This is in agreement with the common perception that braided rivers should not be included in the 
development of regime geometry relationships. However, this discrepancy can be interpreted in another way (see below).

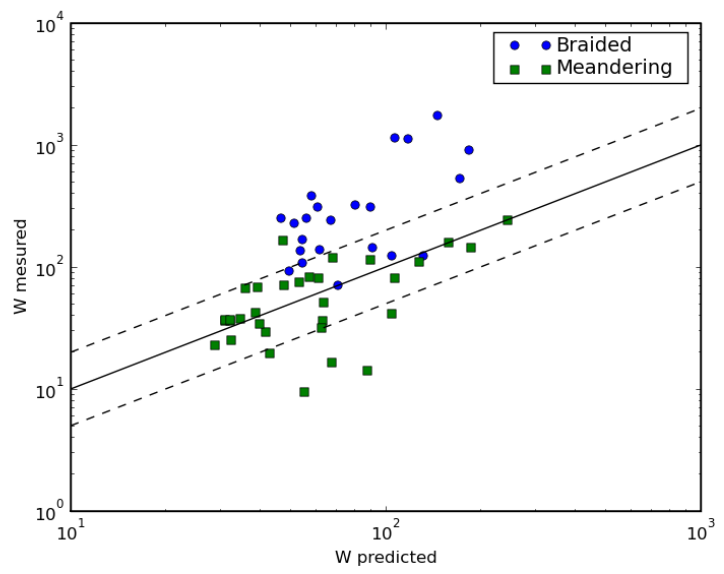

Figure 11: Comparison between measured and predicted bankfull width using (Yalin and da Silva, 2001)'s regime equation for gravel bed streams. The black line corresponds to perfect agreement $W_{\text {meas }}=W_{\text {Pred }}$; dashed lines correspond to $W_{\text {meas }}=2 W_{\text {Pred }}$ and $W_{\text {meas }}=$ $0.5 W_{\text {Pred }}$.

It is useful to calculate the bankfull/critical shear stress ratio $\left(\eta=\tau_{*} / \tau_{*, c r}\right)$. Figure 12 shows the cumulative distribution functions of $\eta$ for both meandering and braided streams, together with the Q-Q distribution plot. It clearly shows that most meandering streams have shear stresses slightly above the critical shear stress, as predicted by fluid mechanical studies. Conversely, braided streams have high shear stresses. Note that the shear stress ratio distributions are dissimilar and hence cannot be modeled using the same probability distributions (Paola, 2001). For meandering streams, the median value $\eta_{50} \sim 1.5$, whereas for braided streams, $\eta \sim 3$. For the same grain size distribution, this results in more than one order of magnitude difference in the sediment flux, confirming the commonly held belief (e.g., Schumm, 2005) that bedload transport is much higher, and probably over a much longer time period, in braided streams than in meandering streams. Figure 12 and the analysis it rests upon thus imply that a change in sediment supply transported as bedload might possibly induce a change in planform.

Only one database allows the influence of bedload on hydraulic geometry and, more specifically, on the criterions proposed by Parker (1976) to be checked. This database was published by King (2004). It contains thirty streams for which both $W / H$ and $S_{c} / \mathbf{F r}$ can be estimated and compared to bedload fluxes at bankfull conditions (we used the bankfull geometry summarized in Mueller and Pitlick 2005), to which we added the values for one stream studied by Ryan and Emmett (2002) (results shown in Figure 1.13). As seen in Figure 13, the influence is striking: bedload changes alone can induce a five-fold change in the aspect ratio and an order of magnitude change in $S_{c} / \mathbf{F r}$. However as the dataset is too 

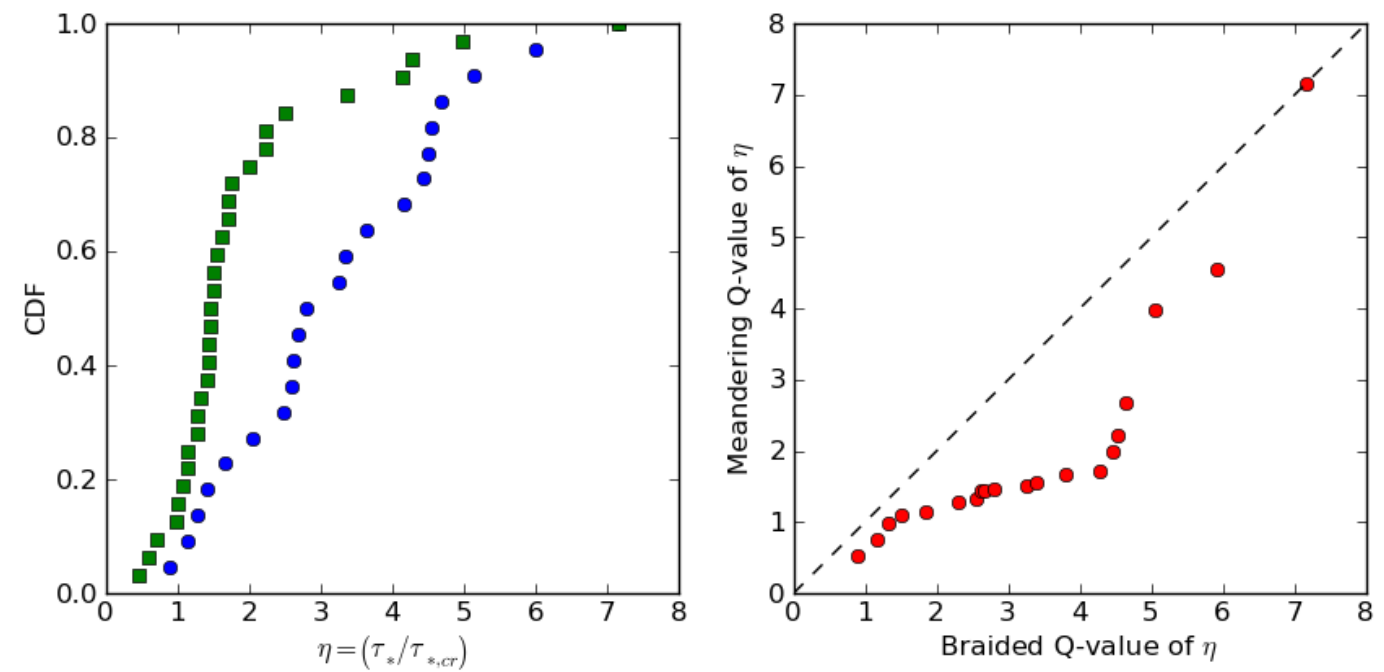

Figure 12: Cumulative distribution functions of $\eta=\tau / \tau_{c}$ for meandering and braided streams in the CRVs dataset. Q-Q plot of these distributions.
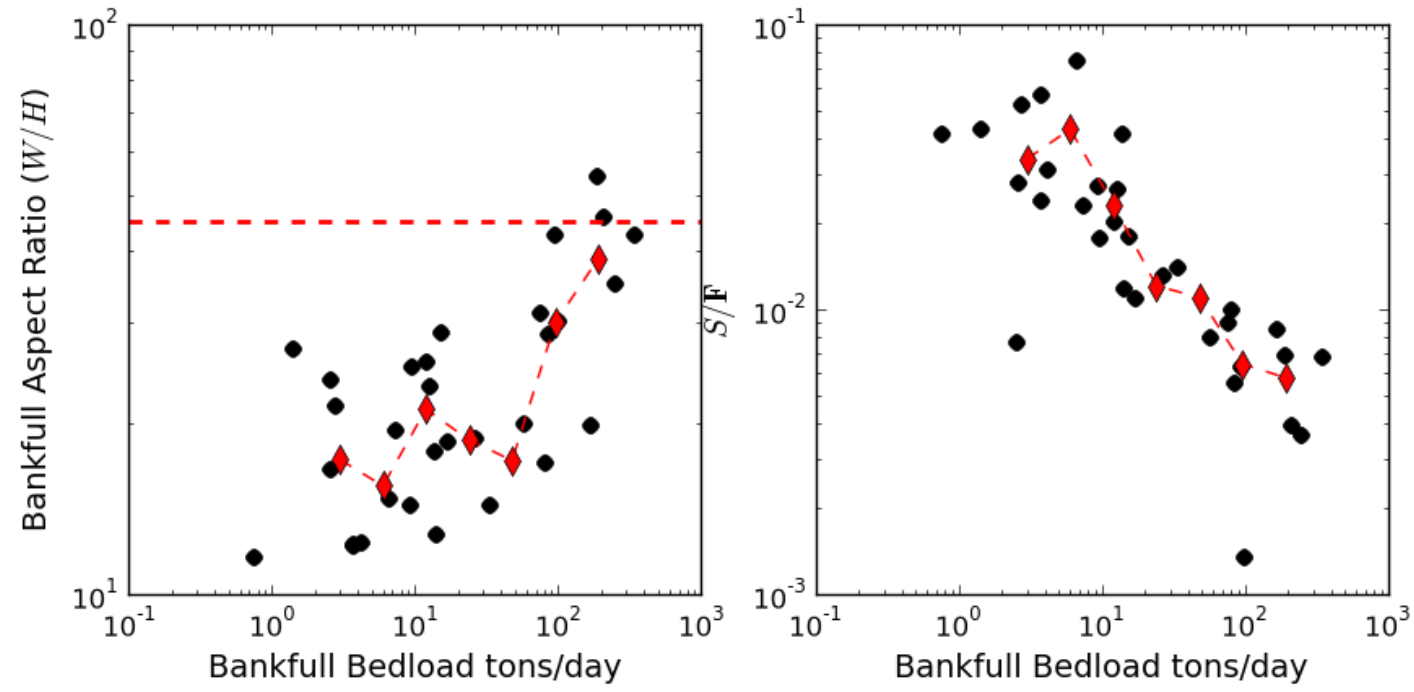

Figure 13: Influence of bedload transport on the aspect ratio (left) and $S / \mathbf{F r}$ (right) during bankfull flow for gravel bed streams in Idaho. Data from King (2004). We used both values of bankfull bedload fluxes reported by King (2004), and Ryan and Emmett (2002) together with bankfull flow conditions values reported by Mueller and Pitlick (2005).Black dots: individual streams, red diamonds: binned averages. 
small and does not contain truely braided streams, a clear and quantified picture does not emerge. Therefore much remains to be done and bedload flux surveys should be carried out on a much wider scale. Yet our analysis compellingly confirms Mackin's (1948) statement that sediment fluxes from the drainages should be considered a first order driver of channel planform and metamorphosis, as a change in bedload supply will undoubtedly lead to a substantial change in the parameters controlling channel morphology. 


\section{THE ROLE OF SOIL PROPERTIES AND VEGETATION ON BANK STABILITY}

The role of bank resistance has long been recognized as a primary control on channel shape (Andrews, 1984; Eaton, 2006; Hey and Thorne, 1986; Huang and Nanson, 1998; Millar, 2000; Montgomery and Buffington, 1997; Rowntree and Dollar, 1999; Schumm, 1960; Smith, 1976). Two factors have been proven to exert a significant control on bank strength and favor their resistance to erosion: (1) soil properties and (2) riparian vegetation.

The respective influence of soil properties versus vegetation on bank strength remains a debated issue, especially for gravel-bed streams. Schumm (1960) analyzed sand-bed rivers in the U.S. Great Plains and demonstrated that clay and silt presence in the bed and banks may critically change bank resistance and therefore control stream aspect ratios. He used this result to classify alluvial streams (Schumm, 1963; Church, 2006). However, Schumm's analysis rests on data acquired in sand-bed streams. It has therefore been argued that clays and silts may not play such an important role in gravel-bed rivers and that vegetation is probably more important in increasing bank stability (Huang and Nanson, 1997; Rowntree and Dollar, 1999).

Three main issues seem to underlie this debate: 1. Is there a well established connection between channel planform and the cohesive properties of banks? 2. Can one define proxies for bank cohesion using simple soil composition properties or other dependant parameters? 3. Under what conditions does vegetation play a role in bank cohesion (whether positive or negative)?

At first, answering any of these points may seem difficult, both because of the mechanisms involved in bank erosion (i.e. mass failure and fluvial bank erosion) and the difficulties in taking in situ measurements of the relevant parameters.

\subsection{Mass failure}

A mass bank failure is when a portion of the riverbank collapses along a slab. A bank stability analysis can be conducted to establish a factor of safety, which represents the balance between gravity forces favoring the mass failure of the bank and bank resistance due to soil cohesion defined by a coulomb criterion (Millar and Quick, 1998; Simon et al., 2000; Parker et al., 2008). This technique has been applied with some success to different gravel-bed streams (Darby et al., 2007; Rinaldi et al., 2008; Luppi et al., 2009). An important issue concerns measurement reproducibility for bank shear resistance. The thorough analysis by Parker et al. (2008) shows that in Goodwin Creek's (Mississippi) temperate soils, the local variability in effective cohesion, friction angle and saturated unit weight are such that averages derived from small sample populations can lead to diametrically opposed conclusions regarding bank stability. Averaging over an entire section does not resolve the problem, leading Parker et al. (2008) to conclude that, given the natural variability of riverbank geotechnical properties, only a probabilistic assessment of the factor of safety that explicitly includes the distribution functions of effective cohesion can result in realistic and unbiased predictions of bank stability 
(Darby et al., 2000; El-Ramly et al., 2002; Parker et al., 2008).

These conclusions leave us with two problems. First, the database needed to derive reasonable distribution functions for a range of gravel-bed stream banks does not yet exist. Second, the approach to study ancient rivers seems limited. As diagenesis occurs, the petrophysical properties of former bank deposits are modified and thus are no longer representative of the conditions prevailing when the river was active.

However, a recent reassessment of bank stability may allow for a more simple, yet accurate, assessment of bank resistance.

Istanbulluoglu et al. (2005) studied the mechanisms by which gullies develop. Starting from a simple geometry, with or without cracks, and assuming a coulomb friction, they calculated a factor of safety. Assuming the factor of safety was equal to 1, they calculated the maximum height a failure block can reach. They then showed that this maximum bank height could be seen as a proxy for cohesion and the internal friction angle. A comparison between measured values of gully bank heights and soil cohesion showed a good correlation. This approach was later adapted by Eaton (2006) to gravel-bed streams in order to constrain a rational regime model using Hey and Thorne's (1986) dataset.

Although promising, this approach must still be rigorously tested on river datasets in different settings and for different vegetation covers. Furthermore, if the concept proves valid, the maximum height should be a constraint for regime models and not a fitting parameter as seen in Eaton (2006).

\subsection{Fluvial bank erosion}

The approach delineated above for bank failure through the factor of safety is also limited. Hydraulic erosion at the base of the bank or even directly on the face can be significant, and it is often mentioned as a key process for the mass failure of the entire overlying bank.

Fluvial erosion is modeled using this equation:

$$
\dot{\epsilon}=k_{d}\left(\tau_{0}-\tau_{c}\right)
$$

where $\dot{\epsilon}$ is the erosion rate in volume per unit area per unit time, $k_{d}$ a detachment rate coefficient called erodibility, $\tau_{0}$ the boundary shear stress and $\tau_{c}$ the critical shear stress required to initiate erosion (Hanson and Cook, 2004, e.g.,). The only reliable method that exists today to perform field measurements of both $k_{d}$ and $\tau_{c}$ relies on using a jet test device (Hanson and Cook, 2004). Hanson and Simon (2001) used jet test measurements to characterize the critical stress of erosion and stream bed erodibility in the Midwestern U.S. Their results highlight the wide range of critical stresses measured as well as the erodibility of the material. Hanson and Simon (2001),Hanson et al. (2007), and Simon and Thomas (2002) showed a remarkable correlation between erodibility and shear stress, both in the field and in the lab.

These important results call for a comparison between such measurements and reach properties. Constantine et al. (2009) made a fundamental step in a study on several meandering reaches of the Sacramento River. They compared bank erodibility measured through 


\begin{tabular}{lccccc}
\hline Source & $\bar{A}$ & $\overline{Q_{b f}}$ & $\bar{H}$ & $\max \left(Q_{b f}\right)$ & $\max \left(H_{b f}\right)$ \\
\hline Andrews (1984) & 1041 & $? 44.2$ & 0.80 & 255 & 1.85 \\
Hey and Thorne (1986) & 196 & 86.1 & 1.42 & 424 & 3.21 \\
Huang and Nanson (1997) & $>20 ?$ & 36.5 & 1.47 & 131 & 3.3 \\
Rowntree and Dollar (1999) & 430 & 116.9 & 1.83 & 407.1 & 2.3 \\
Hession et al. (2003) & 8.5 & NA & 0.39 & NA & 0.74 \\
\hline
\end{tabular}

Table 2: Average drainage area $\left(\mathrm{km}^{2}\right)$, average and maximum discharges $\left(\mathrm{m}^{3} / \mathrm{s}\right)$, and depths (m) recorded in sources containing information on vegetation

the jet apparatus technique to the long-term bank erosion coefficient commonly used to calculate meander migration rates. From repeated planform surveys over a 26-year period, they calculated the erosion coefficient for different reaches and compared it to the erodibility coefficient (Figure 6 in Constantine et al., 2009). The correlation is extremely promising. Furthermore, it shows a clear relationship between both parameter values (erodibility and bank erosion coefficient) and the soil composition of the Sacramento River reaches. If verified on other streams with different sets of conditions, this approach would represent a very efficient way to relate physically measured and geomorphic parameters. However, like for geotechnical properties, the database still needs to be created.

\subsection{The effective role of vegetation}

Significant progress has been made in defining bank cohesion, stability and erodibility and there are now models integrating all these components (Darby et al., 2007; Rinaldi et al., 2008). Yet, the influence of vegetation on observed bank cohesion is still being debated for three reasons.

The first reason for the controversy, as shown in $\S 4$, is that it is possible to derive reasonable first-order hydraulic geometry relationships that do not account for vegetation.

The second reason comes from the observation that the same vegetation type in a forest, for example, may influence channel planforms in opposing ways depending on the catchment size (Zimmerman et al., 1967; Hession et al., 2003).

Despite evidence that forested reaches may be larger than non-forested ones in small catchments, the vast majority of studies on the effect of riparian vegetation on channel morphology have concentrated on rivers with drainage areas largely above the threshold proposed by Zimmerman et al. (1967). Therefore, the role of vegetation on gravel-bed channels is most often associated with increasing bank strength and channel narrowing (Eaton, 2006; Eaton and Giles, 2009; Andrews, 1984; Hey and Thorne, 1986; Huang and Nanson, 1997; Millar, 2000; Simon and Collison, 2002) rather than to widening, erosion and avulsion. Rivers with dense riparian vegetation are invariably described as being deeper and narrower than their grassy counterparts. This is clear from an analysis of the databases of Andrews (1984),Hey and Thorne (1986),Huang and Nanson (1997), Huang and Nanson (1998), and Rowntree and Dollar (1999). Figure 14 shows the CDFs of the aspect ratio for the streams 

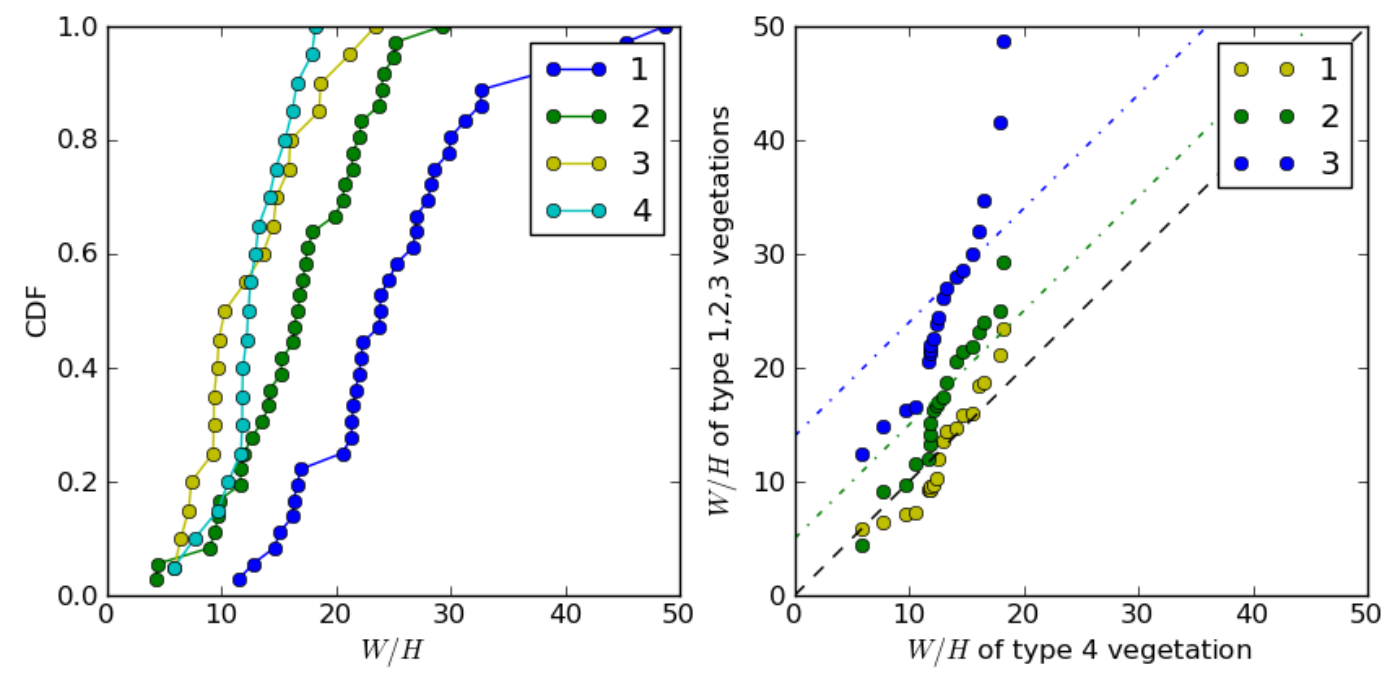

Figure 14: Left: CDFs of $W / H$ for streams according to Hey and Thorne (1986)'s classification, revised by Huang and Nanson (1998). Data from Andrews (1984),Hey and Thorne (1986),Huang and Nanson (1997), and Rowntree and Dollar (1999) . Right: Q-Q plots of the aspect ratio distributions for vegetation types 1, 2 and 3 versus vegetation type 4 . The distributions are similar for types 3 and 4 and tend to become progressively dissimilar as the vegetation contrast increases.

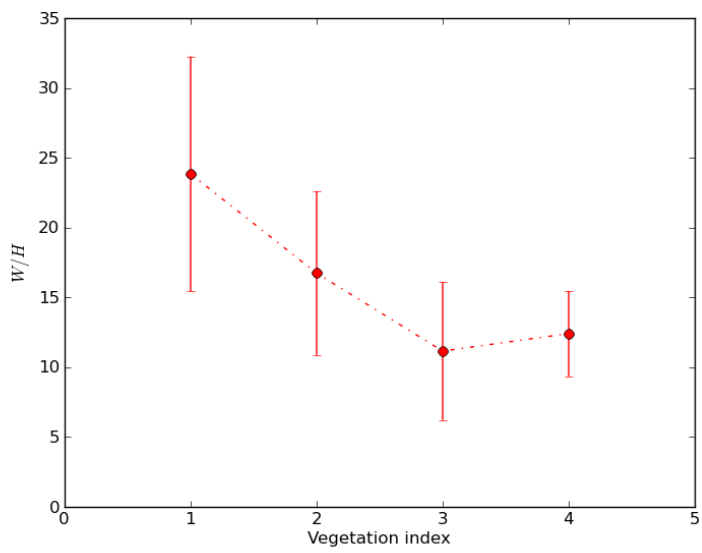

Figure 15: Average values of $W / H$ as a function of the vegetation index. Data from Andrews (1984),Hey and Thorne (1986),Huang and Nanson (1997), and Rowntree and Dollar (1999) . Error bars correspond to $1 \sigma$ of the aspect ratio distribution. 
in this database, grouped by the vegetation index according to Hey and Thorne (1986) and Huang and Nanson (1998). The difference is clear and shows that vegetation exerts a strong influence on the aspect ratio of gravel-bed streams. The median aspect ratio can change by a factor of two if, for example, a riparian forest develops on previously poorly vegetated banks (Figure 15.

The third reason for controversy comes from the gap between available data and theoretical advances on the role of vegetation. Andrews's (1984) and Hey and Thorne's (1986) work was so important that approximately 25 years after publication, they are still the reference datasets against which all hypotheses are tested. Yet, the gap between these existing datasets and the advances made by researchers on the vegetation-added strength to bank soils is rapidly growing. The vegetation index is not a physical parameter and cannot be directly related to shear strength.

The question then became how to relate vegetation to both shear strength and erodibility. Abernethy and Rutherfurd (2000, 2001) made a first step towards this by adopting techniques and procedures used to assess the role of roots in slope stability analysis. They also developed measurements of root tensile strength on river banks for two riparian species (river red gum and swamp paperback) in Australia. Using individual root tensile strength measurements together with a map of root density by root diameter class and with a simple model, they were able to calculate the added resistance to the banks. The results are highly speciesdependant, but the added resistance equals the effective cohesion up to depths of more than $1.7 \mathrm{~m}$ below the tree trunks and 0.4 meters at a distance of 17 meters from the trunks, thus demonstrating the potential influence of vegetation. Others have applied this approach to other species (Simon and Collison, 2002; De Baets et al., 2008) and one hopes to have, in the near future, a compendium of the root-added resistance of a wide variety of species that can be accurately used and applied to model bank resistance and erosion. Many improvements must still be developed to fully understand the mechanical effects of vegetation on river bank stability (Simon and Collison, 2002; Van De Wiel and Darby, 2007). Recent case studies have proven the potential of this approach to precisely assess the relationship between riparian vegetation dynamics and observed effects on channel bank stability, as well environmental consequences (Simon et al., 2006; Pollen-Bankhead et al., 2009).

A change in riparian vegetation therefore stands as a first order driver for changes in stream planform geometry. This result is very similar to both experimental, numerical and field studies that have shown how and under what conditions woodland and vegetation expansion on a braidplain can induce the progressive abandonment of secondary channels, corralling the flow and evolution towards a single thread morphology (e.g., Gran and Paola, 2001; Murray and Paola, 2003; Tal and Paola, 2010).

However, if advances are evident and real for "large" streams, the works of Zimmerman et al. (1967) and Hession et al. (2003) remain important reminders that a large research effort is needed to push our understanding of vegetation effects on smaller first order streams up to the level reached for larger ones. 


\section{THE CHANNEL METAMORPHOSIS RECORD}

Over long time scales (several thousand to several million years), the only way to study the channel metamorphosis of alluvial rivers is to examine the sedimentary deposits where these changes are recorded. Deciphering the latter requires the different river channel types to be identified from the remaining sediments. At the minimum, this requires qualitative paleoenvironmental, and if possible, quantitative paleohydraulic reconstructions.

\subsection{Qualitative paleoenvironmental reconstructions}

Paleoenvironmental reconstructions are based on coupled observations of present and past deposits usually summarized using facies models. A facies model is a conceptual model for the assemblage across space and through time of sedimentary facies (i.e., of sediment bodies characterized by a particular combination of physical, chemical and biological properties) that are genetically linked to a specific depositional environment (Potter, 1959; Walker, 1979). Sedimentologists are now working for fifty years to build facies models for sediments from different stream types. At the beginning of this process, they were inspired by the contemporaneous geomorphological advances on channel geometries (e.g., Miall, 1977; Rust, 1978a; Galloway, 1981). Then, they tried establishing ideal facies models for the alluvial deposits associated with the different channel patterns and rules to recognize them from ancient sediments.

Channel fills During the seventies and eighties, several facies models were provided for gravel-bed braided rivers (e.g., Miall, 1977; Rust, 1978b, 1979; Steel and Thompson, 1983), as well as for meandering streams with coarse sand and fine gravel loads (e.g., McGowen and Garner, 1970; Bridge and Jarvis, 1976; Jackson, 1976; Nijman and Puigdefabregas, 1978). In contrast, works on true gravel-bed meandering rivers remained scarce (Gustavson, 1978; Jackson, 1978; Ori, 1982; Arche, 1983; Forbes, 1983; Massari, 1983). At that time, alluvial facies models were mostly based on the vertical channel-fill sequences associated with the different stream patterns. However, several researchers shown that it is often impossible to distinguish between ancient meandering and braided channel fills from mostly vertical observations and that extensive and three-dimensional outcrop descriptions must be used instead (Jackson, 1978; Eynon and Walker, 1974; Miall, 1980; Bridge, 1985). Consequently, the use of vertical sedimentary profiles to recognize former meandering and braided streams were progressively abandoned.

The most useful approach to differentiate the various channel fill types is now the architectural element approach. An architectural element is defined as a discrete body of sediments with distinctive facies assemblages, facies geometries, bounding surfaces and paleocurrent directions, with an emphasis on their three-dimensional architecture (Allen, 1983; Miall, 1985, 1988, 1996). Genetically, it corresponds to a morpho-sedimentary unit from a specific depositional environment. In stratigraphic successions, architectural elements of different sizes are all fit together into a hierarchy of sediment bodies of differently scales, with each body bound by bedding contacts of various extents, duration and origin. 
Allen (1983) and Ramos and Sopeña (1983) were the first to divide alluvial sediments into architectural elements thanks to detailed work on large outcrops of ancient sandy and gravelly deposits, respectively. Then, in the late eighties and early nineties, Miall (1985, 1988, 1996) asserted general bases to identify architectural elements within alluvial deposits. According to him, only a limited number of basic architectural elements exist (e.g., lateral and downstream accretion bars, thalweg fills, floodplain deposits, etc.) within alluvial systems regardless of their channel pattern, but these elements combine in different ways depending on the organization and dynamics of the rivers. Thereby, the criterion to determine a channel pattern becomes the manner in which the basic elements are assembled together. However, the architectural element approach is more demanding than traditional facies methods. To distinguish the elements and produce reliable paleoenvironmental reconstructions, it is necessary to work on large exposures, have three-dimensional controls and acquire plenty of data. Detailed paleocurrent analyses are also important to compare the direction of sediment accretion within the architectural elements representing bars with the main orientation of the flow.

Based on previous works, Miall $(1985,1996)$ illustrated typical arrangements of architectural elements for several types of stream. He proposed that the channel fill of gravel-bed meandering streams is characterized by gravelly unit bars and gravelly compound bars corresponding to point bars that grow mostly by lateral accretion. Conversely, the channel fill of gravel-bed braided rivers would more likely be primarily composed of gravelly unit bars and compound bars that grow mainly by downstream accretion. Within braided channels, point bars can also form associated with the lateral shifting of thalwegs, but they are less numerous than downstream accreting bars. In braided stream sediments, it is also possible to observe thalweg and bar deposits on a larger-scale range than within meandering channel fills (Williams and Rust, 1969; Bristow, 1987; Bridge and Lunt, 2006). Additionally, confluence scours and fills seem to be important architectural elements of braided alluvia (Huggenberger, 1993; Siegenthaler and Huggenberger, 1993).

Despite subsequent discussions (e.g., Brierley and Hickin, 1991; Bridge, 1993; Miall, 1995; Bridge, 1995), the architectural element approach was widely used to analyze outcrops of ancient gravel-bed stream deposits (e.g., Ramos and Sopeña, 1983; Smith, 1990; DeCelles et al., 1991; Jones et al., 2001). Nevertheless, calibrations of the characteristics of architectural elements in modern rivers were needed to help recognize and interpret them in ancient sediments. Yet, in the early nineties, Smith (1990) noticed that relatively little was known about the structure and dynamics of bars existing in gravel-bed rivers. To fill this gap, many recent studies have focused on the architecture of present-day river bars using aerial and satellite images, topographic surveys, ground-penetrating radar profiles, and core and trench observations (for an outline, see Bridge, 2003; Bridge and Lunt, 2006). However, still relatively few have concentrated on gravel-bed streams (Leclerc and Hickin, 1997; Lunt et al., 2004; Lunt and Bridge, 2004; Wooldridge and Hickin, 2005; Rice et al., 2009). Furthermore, these modern works are carried out only at the scale of one or two compound bars, presumably because they are the emergent and accessible places in active channels. The solution to characterise the architecture of whole channels could be studies on frozen 
river beds or recent channel fills (e.g., Lunt et al., 2004; Lunt and Bridge, 2004; Bersezio et al., 2007; Kostic and Aigner, 2007; Hickin et al., 2009). Though, no quantitative studies have yet been performed on the architectural characteristics proposed as diagnostic criteria for channel patterns (e.g., proportion of lateral versus downstream accretion within channel fills, scale range for embedded thalweg fills and bars, relative amount of preserved deep and shallow deposits). Finally, the works carried out on active streams all deal with depositions over a few decades at the maximum and the problem of sediment preservation over longer timescales remains unresolved.

Grain size Since the seventies, the number of studies on gravel-bed streams is continually growing. However, most of the facies models proposed for gravel-bed meandering rivers are based on present-day (e.g., Gustavson, 1978; Jackson, 1978; Arche, 1983; Forbes, 1983; Brierley, 1989; Smith, 1989; Brierley, 1991; Leclerc and Hickin, 1997) and Quaternary (Maizels, 1983; Campbell and Hendry, 1987; Bersezio et al., 2007; Kostic and Aigner, 2007) channel fills with their planform still visible at Earth's surface. As far as we know, only two cases of older streams (one Pliocene and one Miocene) were recognized as gravel-bed meandering rivers (Ori, 1982; Massari, 1983; Massari et al., 1993). One can thus wonder why so few rivers of this type are described from stratigraphic records.

As discussed above, it is difficult to unambiguously differentiate meandering and braided channel fills on extensive three-dimensional outcrops without a detailed analysis of the deposit architecture and paleocurrents. In addition, with Schumm's classifications in mind, sedimentologists naturally associated gravelly sediments with braided streams (e.g., see Orton and Reading, 1993; Galloway and Hobday, 1996). Similarly, they perceived meandering rivers as mixed load streams, which typically transport sand and finer sediments. Thus, it can be imagined that some ancient gravels interpreted as braided channel fills were in fact meandering ones.

Nevertheless, the few gravelly meandering channel fills described in the stratigraphic record could also result from either a low occurrence in the past or a low preservation potential in the sedimentary series. Indeed, it is possible that the preservation potential of these rivers is limited because they do not carry much bedload (see $\S 4.3$ ). Because of this moderate bedload transport, gravel-bed meandering streams are possibly not aggradational rivers and the chance that their deposits are preserved at geologic time-scales is much less than their braided counterparts, which form most of the large valley fills and alluvial fans in nearby mountain ranges.

\subsection{Quantitative paleohydraulic reconstructions}

Beyond qualitative paleoenvironmental reconstructions, researchers have also tried extracting quantitative information on ancient streams from their sediments. Paleohydraulics is thus a discipline that attempts to determine quantitative data linked to hydraulic parameters of former rivers (such as depth, width, width/depth ratio, sinuosity, slope, discharge, sediment supply, etc.) from measurements made on their preserved deposits. Besides, a 
qualitative reconstruction of the stream pattern is usually needed before any reliable quantitative paleohydraulic analysis. Depending on the observable sediment features, different approaches were then used to reconstruct the geometrical and hydrological characteristics of paleochannels.

For gravel-bed rivers, the most common approach is based on the principels of sediment transport mechanics. It uses the empirical or theoretical relationships established between the sediment grain size and critical flow conditions necessary to initiate the bedload motion (see Church and Gilbert, 1975; Costa, 1983; Williams, 1984, 1988; Maizels, 1989). Workers who attempted paleohydrological quantifications with this approach suggested that these relationships can be used to estimate critical velocities or shear stresses for sediment entrainment from measurements of the gravel size. These measurements can be taken even when the individual bar and channel deposits of ancient gravel-bed rivers are poorly identifiable. However, the local sedimentary structures or regional gradients can be clear enough to allow the assessment of additional parameters such as flow depth or valley slope. Flow depth is usually derived from the size of sedimentary structures produced by the formation and migration of bedforms such as bars or dunes (e.g., Jopling, 1966; Paloa and Borgman, 1991; Leclair and Bridge, 2001). The slope is usually derived from terrace gradients. The grain size, together with the depth or slope, are then used to infer the missing parameter at the threshold of motion. Once these three parameters are assessed, some studies then calculate the paleo-velocities and unit discharges. Finally, if the former channels are still visible at Earth?s surface or if their width can be measured by another mean, their discharge can be also estimated. With this methodology, paleohydraulic reconstructions have been performed for present-day floods (Bradley and Mears, 1980; Costa, 1983; Mack et al., 2008), as well as for ancient gravel-bed channels lying on recent terraces (e.g., Birkland, 1968; Malde, 1968; Baker, 1973, 1974; Church, 1978; Maizels, 1983; Ryder and Church, 1986; O'connor and Baker, 1992) or in valley and basin fills (Allen and Mange-Rajetzky, 1982; Goodwin and Diffendal, 1987; Heller and Paola, 1989; Jones and Frostick, 2008). One can mention also that Jones and Frostick (2008) recently coupled a study of this kind with a volumetric analysis of gravel bar deposits to assess ancient bedload transport rates.

However, this first approach has limitations. First, there are inherent problems associated with uncertainties in measurements of grain size distributions, paleodepths and paleoslope. Second, this approach only assesses instantaneous paleoflow conditions from the sediment units sampled, the overall long-term significance of which is hard to judge. The forecasted instantaneous conditions are often peak velocities, depths and discharges, which can be very difficult to relate to the average or bankfull behavior of the corresponding streams. In addition, flood recurrence intervals most often remain unknown. Consequently, even if reasonable first-order paleohydrological reconstructions seem possible based on critical motion theories (see Baker and Ritter, 1975; Bridge, 1981; Church et al., 1990; Paola and Morhrig, 1996), workers must not forget that they are order-of-magnitude exercises (see Church, 1978; Ryder and Church, 1986).

This first approach can be coupled with a second one based on the hydraulic geometry concept (see $\S 4$ ). It uses the empirical relationships established between the channel mor- 
phology and controlling factors of some present-day rivers (see Ethridge and Schumm, 1978; Gardner, 1983; Williams, 1984, 1988). Researchers who performed the foremost attempts of paleohydraulic reconstructions proposed that these semi-empirical relationships can be extrapolated to ancient streams (Dury, 1965; Moody-Stuart, 1966; Schumm, 1968a; Cotter, 1971; Schumm, 1972). Accordingly, they used these relationships to estimate the hydrological characteristics of paleochannels where one or several of their original dimensions can be indentified and measured in map views or cross-sections at Earth's surface or within stratigraphic successions. From these measurements, parameters such as channel width, depth, cross-section area, meander wavelength or sinuosity can be estimated. These can then be put into the equations established for river morphology and hydrology to calculate width, meander wavelength or sinuosity (if they cannot be observed), as well as values for mean annual and mean annual flood discharges, channel and valley slopes, mean flow velocities, drainage areas or stream lengths. This methodology is useful as it deals with the long-term, statistical averages of hydraulic parameters.

However, this approach has mostly been used to perform paleohydraulic reconstructions for sand-bed streams (e.g., Dury, 1965; Moody-Stuart, 1966; Cotter, 1971; Schumm, 1972; Leeder, 1973; Sylvia and Galloway, 2006), but rarely for gravel-bed rivers (Steer and Abbott, 1984; Eriksson et al., 2006). Moreover, like the first paleohydraulic methodology, it has significant limitations. First, it is not always easy to recognize and measure true individual fills of channels that were active at a single time from the sedimentary series. Furthermore, most paleohydraulic studies based on hydraulic geometry relationships use empirical equations calibrated on specific rivers, which are not necessarily representative of present-day streams around the world, nor of the ancient rivers that have constructed stratigraphic successions. Finally, substituting certain variables (e.g., maximum depth instead of mean depth) or applying equations developed for one system to another one (e.g., relationships developed for sand-bed, single thread or straight streams used for paleohydraulic reconstructions of finerand coarser-grained, braided or sinuous channels) can also result in significant errors. Any future improvements to the completeness and consistency of the database on which hydraulic geometry relationships are based would therefore make the derived paleohydraulic reconstructions more efficient.

Using a third approach, Robertson-Rintoul and Richards (1993) proposed that channel planform features are better paleohydraulic proxies than cross-sectional ones. They determined an braiding intensity index corresponding to the mean density/mean length ratio of threads for channels still visible at terrace surfaces. Using this parameter along with terrace slopes and grain sizes, they then calculated the former mean annual flood discharges. However, this methodology cannot be applied without map views of the ancient rivers. Moreover, even on recent terraces, it is difficult to recognize and measure the threads active at a single time.

While several results from paleohydraulic works performed for sand-bed streams have occasionally been homogenized and compiled (Leeder, 1973; Ethridge and Schumm, 1978), this was not done for gravel-bed rivers. Although, even if these estimates only have a first-order value, it would be interesting to compile them in order to compare databases for present-day 
and ancient channel features. The problem is that paleohydraulic reconstructions performed for gravel-bed streams lack consistency in how the basic input variables are quantified. For example, although it is often used as a major input parameter, there is no consensus on how to characterize the grain size (e.g., diameter of the largest clast, mean of the diameters of the ten or twenty-five largest clasts, $D_{50}, D_{84}, D_{90}$ or $D_{95}$ of granulometric distributions determined by random counting or sieving). Hence, compiling existing paleohydraulic data for gravel-bed channels is a difficult task. In fact, it might be necessary to adopt common measurement and assessment procedures before it can be done.

\subsection{Gravel-bed channel metamorphosis}

Within stratigraphic successions, many changes in stream patterns from meandering to braided or vice-versa have been documented (e.g., Fisk, 1947; Nami and Leeder, 1978; Maizels, 1983; Miall, 1984; Fielding et al., 1993; Ward et al., 2000; Kostic and Aigner, 2007). However, most of these works concern the metamorphosis of sand-bed channels. Only two studies mention changes of gravel-bed rivers from one pattern to another (Maizels, 1983; Kostic and Aigner, 2007). Furthermore, these changes are not simple channel pattern transformations as they are associated with changes in stream behavior from aggradation to incision, or vice-versa. In fact, the simple metamorphoses involving gravel-bed channels are more often associated with grain size changes. Indeed, transitions between gravel-bed braided streams and sand-bed meandering streams, with or without sand-bed braided transitional stages, are commonly observed within stratigraphic successions (e.g., Fisk, 1947; Miall, 1984; Huisink, 1997; Nakayama and Ulak, 1999).

In any case, the reasons proposed for such metamorphoses are usually the same, irrespective of the grain size. Workers associate the transformations between braided and meandering streams with modifications in water discharge, sediment supply (amount and grain size) or slope brought on by climatic changes, tectonic uplifts or sea level rises and falls. They also evoke the influence of terrestrial plants with well-developed root systems (e.g., Schumm, 1968b; Cotter, 1978; Long, 1978; Huisink, 1997; Ward et al., 2000). However, case studies that attempt to quantify the paleohydraulic factors that change during channel metamorphosis remain scarce (Maizels, 1983). 


\section{DISCUSSION AND CONCLUSIVE REMARKS}

We would like to summarize and briefly discuss the problems we have identified from our review of the literature and which we believe call for further research in the near future. These fall into three main categories: (1) theoretical approaches, (2) data acquisition particularly database development, and more specifically the problems posed by gravel-bed rivers, and (3) meandering streams.

\subsection{Concepts and theory}

From a theoretical point of view, it seems clear that many major advances have been made since Lane's quote in 1955. Research on bank stability and erosion has led to many advances and we are now in the process of fully integrating vegetation as a component of the physical description of river banks.

Fluid mechanics has been an essential tool in understanding the importance of the shear stress distribution across the flow section and in defining conditions of stability in rivers. There is still much debate among researchers on the conditions that define hydraulic geometry and it probably stems from two main points. First, we still lack a clear understanding of what sets the width of a stream. Second, because boundary fluxes are almost never measured, bedload is considered a dependant variable, although as nicely stated by Mackin (1948), the river does not decide what bedload it can carry but rather adapts to carry the imposed load.

In the domain of qualitative plaeoenvironmental reconstructions, the proposed diagnostic criteria to discriminate between deposits of meandering and braided paleochannels (e.g., ratio of lateral versus downstream accretion, scale ranges of enbedded thalweg fills and bars, relative amount of deep and shallow deposits preserved) which have left no visible tracks in plan view, still need validation from studies on present gravel-bed and sand-bed rivers. However, if these conceptual advances still lack confirmation through well-defined case studies, it is often because of practical problems of accessibility to whole active reaches occupied by the flow. To get around such a problem, studies on frozen river beds or on recent channel fills seem to be promising.

\subsection{Databases: when harmony rules the world}

It is the opinion of the authors that databases are the most compelling and urgent problem that the community has to tackle in the near future. For hydraulic geometry and channel pattern, all model tests and applications rely on data that were acquired more than 20 years ago. The Van den Berg compendium is not an exception as most of the new rivers come from personnal communication of M.P. Mosley. Field surveys have been performed but are very difficult to find. In recent years, surveys like the ones performed by McCandless and Everett (2002); McCandless (2003); King (2004); Ryan and Emmett (2002) in Maryland, Idaho and Wyoming should have reached a much wider audience. Reports are often hard to find. The compendium of Parker is a welcome effort but it does not retain the original datasets in their entirety and it includes references that do not always link to the data but 
rather to articles that mention the data. It is the responsibility of journal editors to require that datasets be made available as electronic supplemental material. As a community, it is up to us to define a consistent set of parameters that we then hold ourselves responsible to measure each time we survey a new stream and that we make this data widely available.

From a simple examination of existing databases, it is clear that we lack data on large gravel-bed meandering streams, small braided streams, fine gravel streams, and bedload fluxes. As previously mentioned, until we acknowledge that bedload is not a dependant variable but an imposed boundary condition, hydraulic geometry relationships will be biased because they do not take into account the variable that likely exerts a first order control on channel pattern. For the same reason, datasets including information on bank strength and vegetation-added strength are urgently needed for a wide range of streams.

As for ancient gravel-bed systems, we lack everything. The only databases that report paleochannel dimensions and potential paleohydraulic parameters were compiled for sandbedded streams. As far as we know, at present they are only few tens of quantitative studies performed on deposits of ancient gravel-bed streams and they are neither homogenized nor homogenize-able. How can we discuss the existence and form of pristine streams in temperate countries if we do not even know what the channel planforms were during the Quaternary and before mankind? Finally, trying to harmonize data scattered amongst tens or more articles is a painful experience. Each of us should try to produce one line of normalized information for each new river that we study in order to fill in existing datasets.

\subsection{Are gravel bed meanders pristine ?}

In 1963, Schumm made a small comment (see its p. 7) regarding small meandering gravelbed streams in mountain meadows that should be suspended load channels yet have coarse channel beds. His conclusion was that they are remnants of periods of higher discharge and that the load was not moving most of the time. More recently Walter and Merritts (2008) even argued that the meandering gravel bed streams of Pennsylvania, Delaware and Maryland were not natural but the result of human pertubation of previously anabranching channels and wetlands.

A review of the stratigraphic literature leads to a converging picture. There are very few gravel-bed meandering channels described within sedimentary series. Several reasons for this have been put forward.

First, it is difficult to unambiguously differentiate between a meandering and braided channel in the stratigraphic record because this requires extensive three-dimensional outcrops and detailed analysis on deposit architecture and paleocurrents.

Second, it is possible that very few gravel-bed meandering streams are actually preserved because analysis of the literature persistently leads to the conclusion that these rivers do not carry much bedload. bedload movement would essentially correspond to internal reworking that maintains dynamic meandering by erosion on outer banks and deposition on downstream bars. Thus, gravel-bed meandering streams seem not to be aggrading rivers and therefore their preservation potential in the geologic record is much less than their braided counterparts, which form most of the large alluvial fans at the piedmonts of mountain ranges. 
Third, once again after Schumm, it seems that meandering development is related to the development of vegetation. No meandering streams are recorded before Silurian times which is when vegetation with well developed root systems appeared on Earth.

Let us then finish this review by recalling one of the limitations of our work that need further investigation. We did not go through the literature concerning wandering streams. It may be therefore necessary to look more carefully at these streams as they could represent the natural form of active gravel bed sinuous streams in vegetated floodplains.

\section{Acknowledgments}

We are indebted to Michal Tal, Mike Church and John Pitlick for their patience in reviewing the first draft of the document and their encouragements. Acknowledgments are also due to Sara Mullin for its editorial assistance that helped us to improve the language quality of this article

\section{References}

Abernethy, B., Rutherfurd, I. D., 2000. The effect of riparian tree roots on the mass-stability of riverbanks. Earth Surface Processes and Landforms 25 (9), 921-937.

Abernethy, B., Rutherfurd, I. D., 2001. The distribution and strength of riparian tree roots in relation to riverbank reinforcement. Hydrological Processes 15 (1).

Allen, J. R. L., 1983. Studies in fluviatile sedimentation: Bars, bar-complexes and sandstone sheet (low-sinuosity braided streams) in the brownstones (lower devonian), welsh borders. Sedimentary Geology 33, 237-293.

Allen, P. A., Mange-Rajetzky, M., 1982. Sediment dispersal and paleohydraulics of oligocene rivers in the eastern ebro basin. Sedimentology 29, 705-716.

Andrews, E. D., 1984. Bed-material entrainment and hydraulic geometry of gravel-bed rivers in colorado. Bulletin of the Geological Society of America 95 (3), 371.

Andrews, E. D., 1994. Marginal bed load transport in a gravel bed stream, sagehen creek, california. wrr 30, 2241-2250.

Arche, A., 1983. Coarse-grained meander lob deposits in te jarama river, madrid, spain. In: Collison, J. D., Lewin, J. (Eds.), Modern and ancient fluvial systems. Vol. 6. Ch. Special Publications of the International Association of Sedimentologists, pp. 313-321.

Ashworth, P. J., Freguson, R. I., Ashmore, P. E., Paola, C., Powell, D. M., Prestegaard, K. L., 1992. Measurements in a braided river chute and lobe 2. sorting of bed load during entrainment, transport and deposition. Water Resources Research 28, 1887-1896. 
Baker, V. R., 1973. Paleohydrology and sedimentology of lake missoula flooding in eastern washington. Geological Society of America Special Paper 144, 79.

Baker, V. R., 1974. Paleohydraulic interpretation of quaternary alluvium near golden, colorada. Quaternary Research 4, 94-112.

Baker, V. R., Ritter, D. F., 1975. Competence of rivers to transport coarse bedload material. Geological Society of America Bulletin 86, 975-978.

Bersezio, R., Giudici, M., Mele, M., 2007. Combining sedimentological and geophysical data for high-resolution 3-d mapping of fluvial architectural elements in the quaternary po plain (italy). Sedimentary Geology 202, 230-248.

Birkland, P. W., 1968. Mean velocities and boulder tranport during tahoe-age floods of the truckee river, california-nevada. Geological Society of America Bulletin 79, 137-142.

Blizard, C., Wohl, E., 1998. Relationships between hydraulic variables and bedload transport in a subalpine channel, colorado rocky mountains, u.s.a. Geomorphology 22.

Bradley, W. C., Mears, A. I., 1980. Calculations of flow needed to transport coarse fraction of boulder creek alluvium at boulder, colorado: Summary. Geological Society of America Bulletin 91, 135-138.

Brice, J. C., 1975. Air photo interpretation of the form and behavior of alluvial rivers. Final Report to the US Army Research Office, Durham.

Bridge, J. S., 1981. Hydraulic interpretation of grain-size distribution using a physical model for bedload transport. Journal of Sedimentary Petrology 51, 1109-1124.

Bridge, J. S., 1985. Paleochannel patterns inferred from alluvial deposits: A critical evaluation. Journal of Sedimentary Petrology 55, 579-589.

Bridge, J. S., 1993. Description and interpretation of fluvial deposits: A critical perspective. Sedimentology 40, 801-810.

Bridge, J. S., 1995. Description and interpretation of fluvial deposits: A critical perspective - reply. Sedimentology 42, 384-389.

Bridge, J. S., 2003. Rivers and floodplains. Blackwell Publishing.

Bridge, J. S., Jarvis, J., 1976. Flow and sedimentary processes in the meandering river south esk, glen clova, scotland. Earth and Surface Processes 1, 303-336.

Bridge, J. S., Lunt, I. A., 2006. Depositional models of braided rivers. In: Sambrook Smith, G. H., Best, J. L., Bristow, C. S., Petts, G. (Eds.), Braided rivers: Process, deposits, ecology and management. Vol. 36. Ch. Special Publications of the International Association of Sedimentologists, pp. 11-50. 
Brierley, G. J., 1989. River planform facies models: The sedimentology of braided, wandering and meandering reaches of the squamish river, british columbia. Sedimentary Geology 61, $17-35$.

Brierley, G. J., 1991. Bar sedimentology of the squamish river, british columbia: Definition and application of morphostratigraphic units. Journal of Sedimentary Petrology 61, 211225 .

Brierley, G. J., Hickin, E. J., 1991. Channel planform as non-controlling factor in fluvial sedimentology: The case of the squamish river floodplain, british columbia. Sedimentary Geology 75, 67-83.

Bristow, C. S., 1987. Brahmaputra river: Channel migration and deposition. In: Ethridge, F. G., Flores, R. M., Harvey, M. D. (Eds.), Recent developments in fluvial sedimentology. Vol. 39. Ch. Special Publications of the Society of Economic Paleontologists and Mineralogists, pp. 63-74.

Brownlie, W. R., 1981a. Compilation of alluvial channel data: laboratory and field. Tech. rep.

Brownlie, W. R., 1981b. Prediction of flow depth and sediment discharge in open channels. Tech. rep.

Campbell, J. E., Hendry, H. E., 1987. Anatomy of a gravelly meander lobe in the saskatchewan river, near nipawin, canada. In: Ethridge, F. G., Flores, R. M., Harvey, M. D. (Eds.), Recent developments in fluvial sedimentology. Vol. 39. Ch. Special Publications of the Society of Economic Paleontologists and Mineralogists, pp. 179-189.

Carson, M. A., 1984. The meandering-braided river threshold: a reappraisal. Journal of hydrology(Amsterdam) 73, 315-334.

Church, M., 1978. Paleohydrological reconstructions from a holocene valley fill. In: Miall, A. D. (Ed.), Fluvial sedimentology. Vol. 5. Ch. Memoirs of the Canadian Society of Petroleum Geologists, pp. 743-772.

Church, M., 2006. Bed material transport and the morphology of alluvial river channels. Annual Reviews.

Church, M., Gilbert, R., 1975. Proglacial fluvial and lacustrine environments. In: Jopling, A. V., McDonald, B. C. (Eds.), Glaciofluvial and glaciolacustrine sedimentation. Vol. 23. Ch. Special Publications of the Society of Economic Paleontologists and Mineralogists, pp. $22-100$.

Church, M., Rood, K., 1983. Catalogue of alluvial river channel regime data. Univ. British Columbia, Department of Geography, Vancouver. 
Church, M., Wolcott, J., Maizels, J. K., 1990. Paleovelocity: A parsimonious proposal. Earth and Surface Processes and Landforms 15, 475-480.

Constantine, C. R., Dunne, T., Hanson, G. J., 2009. Examining the physical meaning of the bank erosion coefficient used in meander migration modeling. Geomorphology 106 (3-4), $242-252$.

Costa, J. E., 1983. Paleohydraulic reconstruction of flash-flood peaks from boulder deposits in the colorado front range. Geological Society of America Bulletin 94, 986-1004.

Cotter, E., 1971. Paleoflow characteristics of a late cretaceous river in utha from analysis of sedimentary structures in the ferron sandstone. Journal of Sedimentary Petrology 41, 129-138.

Cotter, E., 1978. The evolution of fluvial style, with special reference to the central appalachian paleozoic. In: Miall, A. D. (Ed.), Fluvial sedimentology. Vol. 5. Ch. Memoirs of the Canadian Society of Petroleum Geologists, pp. 361-383.

Darby, S. E., Gessler, D., Thorne, C. R., 2000. Technical communications-computer program for stability analysis of steep, cohesive riverbanks. Earth Surface Processes and Landforms 25 (2), 175-190.

Darby, S. E., Rinaldi, M., Dapporto, S., 2007. Coupled simulations of fluvial erosion and mass wasting for cohesive river banks. Journal of Geophysical Research-Earth Surface 112, -03022 .

De Baets, S., Poesen, J., Reubens, B., Wemans, K., De Baerdemaeker, J., Muys, B., 2008. Root tensile strength and root distribution of typical mediterranean plant species and their contribution to soil shear strength. Plant and Soil 305 (1), 207-226.

DeCelles, P. G., Gray, M. B., Ridgway, R. B., Cole, R. B., Pivnik, D. A., Pequera, N., Srivastava, P., 1991. Controls on synorogenic alluvial-fan architecture, bertooth conglomerate (palaeocene), wyoming and montana. Sedimentology 38, 567-590.

Diplas, P., 1990. Characteristics of self-formed straight channels. jhe 116, 707-728.

Dury, G. H., 1965. Theorical impliations of underfit streams. USGS Professional Paper 452C, 43.

Eaton, B. C., 2006. Bank stability analysis for regime models of vegetated gravel bed rivers. Earth Surface Processes and Landforms 31 (11), 1438-1444.

Eaton, B. C., Church, M., Millar, R. G., 2004. Rational regime model of alluvial channel morphology and response. Earth Surface Processes and Landforms 29 (4), 511-529.

Eaton, B. C., Giles, T. R., 2009. Assessing the effect of vegetation-related bank strength on channel morphology and stability in gravel-bed streams using numerical models. Earth Surface Processes and Landforms 34 (5), 712-724. 
Eaton, B. C., Millar, R. G., 2004. Optimal alluvial channel width under a bank stability constraint. Geomorphology 62 (1-2), 35-45.

El-Ramly, H., Morgenstern, N. R., Cruden, D. M., 2002. Probabilistic slope stability analysis for practice. Canadian Geotechnical Journal 39 (3), 665-683.

Eriksson, P. G., Bumby, A. J., Brümer, J. J., van der Neut, M., 2006. Precambrian fluvial deposits: Enigmatic paleohydrological data from the c. 2-1.9 ga waterberg group, south africa. Sedimentary Geology 190, 25-46.

Ethridge, F. G., Schumm, S. A., 1978. Reconstructing paleochannel morphologic and flow characteristics: Methodology, limitations and assessement. In: Miall, A. D. (Ed.), Fluvial sedimentology. Vol. 5. Ch. Memoirs of the Canadian Society of Petroleum Geologists, pp. 703-719.

Eynon, G., Walker, R. G., 1974. Facies relationships in pleistocene outwash gravels, southern ontario: A model for bar growth in braided rivers. Sedimentology 21, 43-70.

Fielding, C. R., Falkner, A. J., Scott, S. G., 1993. Fluvial response to foreland basin overfilling; the late permian rangal coal measures in the bowen basin, queensland, australia. Sedimentary Geology 85, 475-497.

Fisk, H. N., 1947. Fine-grained alluvial deposits and their effect on Mississippi River activity. US Army Corps of Engineers, Mississippi River Commission.

Forbes, D. L., 1983. Morphology and sedimentology of a sinuous gravel-bed channel system: Lower babbage river, yukon coastal plain, canada. In: Collison, J. D., Lewin, J. (Eds.), Modern and ancient fluvial systems. Vol. 6. Ch. Special Publications of the International Association of Sedimentologists, pp. 195-206.

Friend, P. F., Sinha, R., 1993. Braiding and meandering parameters. In: Best, J. L., Bristow, C. S. (Eds.), Braided rivers. Vol. 75. Ch. Special Publications of the Geological Society, pp. 105-111.

Galloway, W. E., 1981. Depositional architecture of cenozoic gulf coastal plain fluvial systems. In: Ethridge, F. G., Flores, R. M. (Eds.), Recent and ancient nonmarine depositional environments: Models for exploration. Vol. 31. Ch. Special Publications of the Society of Economic Paleontologists and Mineralogists, pp. 127-155.

Galloway, W. E., Hobday, D. K., 1996. Terrigenous clastic depositional systems: Applications to fossil fuel and groundwater resources. Springer.

Garcia, M. H., 2008. Sediment transport and morphodynamics. In: Garcia, M. H. (Ed.), Sedimentation engineering: processes, management, modeling, and practice. Vol. 110. ASCE, Ch. 2, pp. 21-163. 
Gardner, T. W., 1983. Paleohydrology and paleomorphology of a carboniferous, meandering, fluvial sandstone. Journal of Sedimentary Petrology 53, 991-1005.

Goodwin, R. G., Diffendal, R. F., 1987. Paleohydrology of some ogallala (neogene) stream in the southern panhandle of bebraska. In: Ethridge, F. G., Flores, R. M., Harvey, M. D. (Eds.), Recent developments in fluvial sedimentology. Vol. 39. Ch. Special Publications of the Society of Economic Paleontologists and Mineralogists, pp. 149-157.

Gran, K., Paola, C., 2001. Riparian vegetation controls on braided stream dynamics. Water Resources Research 37 (12).

Gurnell, A. M., Piegay, H., Swanson, F. J., Gregory, S. V., 2002. Large wood and fluvial processes. Freshwater Biology 47 (4), 601-619.

Gustavson, T. C., 1978. Bed forms and stratification types of modern gravel meander lobes, nueces river, texas. Sedimentology 25, 401-426.

Hanson, G. J., Cook, K. R., 2004. Apparatus, test procedures, and analytical methods to measure soil erodibility in situ. Applied Engineering in Agriculture 20 (4), 455-462.

Hanson, G. J., Hunt, S. L., USDA, A., 2007. Lessons learned using laboratory jet method to measure soil erodibility of compacted soils.

Hanson, G. J., Simon, A., 2001. Erodibility of cohesive streambeds in the loess area of the midwestern usa. Hydrological Processes 15 (1), 23-38.

Heller, P. L., Paola, C., 1989. The paradox of lower cretaceous gravels and the initiation of thrusting in the servier orogenic belt, united states western interior. Geological Society of America Bulletin 101, 864-875.

Hession, W. C., Pizzuto, J. E., Johnson, T. E., Horwitz, R. J., 2003. Influence of bank vegetation on channel morphology in rural and urban watersheds. Geology 31 (2), 147.

Hey, R. D., Thorne, C. R., 1986. Stable channels with mobile gravel beds. Journal of Hydraulic Engineering 112 (8), 671-689.

Hickin, A. S., Kerr, B., Barchyn, T. E., Paulen, R. C., 2009. Using round-penetrating radar and capacity coupled resistivity to investigate 3 -d fluvial architecture and grain-size distribution of gravel floodplain in northeast british columbia, canada. Journal of Sedimentary Research 79, 457-477.

Huang, H. Q., Nanson, G. C., 1997. Vegetation and channel variation; a case study of four small streams in southeastern australia. Geomorphology 18 (3-4), 237-249.

Huang, H. Q., Nanson, G. C., 1998. The influence of bank strength on channel geometry: an integrated analysis of some observations. Earth Surface Processes and Landforms 23 (10). 
Huang, H. Q., Warner, R. F., 1995. The multivariate controls of hydraulic geometry: A causal investigation in terms of boundary shear distribution. Earth Surface Processes and Landforms 20 (2).

Huggenberger, P., 1993. Radar facies: Recognition of facies patterns and heterogeneities within pleistocene rhine gravels, ne switzerland. In: Best, J. L., Bristow, C. S. (Eds.), Braided rivers. Vol. 75. Ch. Special Publications of the Geological Society, pp. 163-176.

Huisink, M., 1997. Late-glacial sedimentological and morphological changes in lowland river in response to climatic change: the maas, southern netherlands. Journal of Quaternary Science 12, 209-223.

Istanbulluoglu, E., Bras, R. L., Flores-Cervantes, H., Tucker, G. E., 2005. Implications of bank failures and fluvial erosion for gully development: Field observations and modeling. Journal of Geophysical Research 110 (F1).

Jackson, R. G., 1976. Depositional model of point bar in the lower wabash river. Journal of Sedimentary Petrology 46, 579-594.

Jackson, R. G., 1978. Preliminary evaluation of lithofacies models for meandering alluvial streams. In: Miall, A. D. (Ed.), Fluvial sedimentology. Vol. 5. Ch. Memoirs of the Canadian Society of Petroleum Geologists, pp. 543-576.

Jones, S. J., Frostick, L. E., 2008. Inferring bedload transport from stratigraphic successions: Examples from cenozoic and pleistocene rivers, south central pyrenees, spain. In: Gallagher, K., Jones, S. J., Wainwright, J. (Eds.), Landscapes evolution: Denudation, climate and tectonics over different time and space scales. Vol. 296. Ch. Special Publications of the Geological Society, pp. 129-145.

Jones, S. J., Frostick, L. E., Astin, T. R., 2001. Braided stream and flood plain architecture: The rio vero formation, spanish pyrenees. Sedimentary Geology 139, 229-260.

Jopling, A. V., 1966. Some principles and techniques used in reconstructing the hydraulic parameters of paleo-flow regime. Journal of Sedimentary Petrology 36, 5-49.

Kean, J. W., Smith, J. D., 2005. Generation and verification of theoretical rating curves in the whitewater river basin, kansas. Journal of Geophysical Research 110 (F4), -04012.

King, John G.; Emmett, W. W. W. P. J. K. R. P. B. J. J., 2004. Sediment transport data and related information for selected coarse-bed streams and rivers in idaho. Gen. tech. rep. rmrs-gtr-131. fort collins, co, U.S. Department of Agriculture, Forest Service, Rocky Mountain Research Station.

Knight, D. W., 1981. Boundary shear in smooth and rough channels. Journal of the Hydraulics Division 107 (7), 839-851. 
Kostic, B., Aigner, T., 2007. Sedimentary architecture and 3-d ground-penetrating radar analysis of gravelly meandering river deposits (neckar valley, sw germany). Sedimentology $54,789-808$.

Lane, E. W., 1937. Stable channels in erodible material. Trans. American Society of Civil Engineers 102.

Lane, E. W., 1955. The importance of fluvial morphology in hydraulic engineering 81 (745), $1-17$.

Lane, E. W., 1957. A study of the shape of channels formed by natural streams flowing in erodible material. Tech. rep.

Leclair, S. F., Bridge, J. S., 2001. Quantitative interpretation of sedimentary structures formed by river dunes. Journal of Sedimentary Research 71, 713-716.

Leclerc, R. F., Hickin, E. J., 1997. The internal structure of scrolled floodplain deposits based on ground-penetrating radar, north thompson river, british columbia. Geomorphology 21, $17-38$.

Leeder, M. R., 1973. Fluvial fining-upwards cycles and the magnitude of paleochannels. Geological Magazine 110, 265-276.

Leopold, L. B., Maddock, T. J., 1953. The hydraulic geometry of stream channels and some physiographic implications. usgspp 252.

Leopold, L. B., Wolman, M. G., 1957. River channel patterns. Tech. Rep. 282-B.

Lewin, J., Brewer, P. A., 2001. Predicting channel patterns. Geomorphology 40, 329-339.

Liu, Y., Métivier, F., Lajeunesse, E., Lancien, P., C., N., Meunier, P., 2008. Measuring bed load in gravel-bed mountain rivers : averaging methods and sampling strategies. In: Geodinamica Acta. Vol. 21. pp. 81-92.

Long, D. G., 1978. Proterozoic stream deposits: Some problems of recognition and interpretation of ancient sandy fluvial systems. In: Miall, A. D. (Ed.), Fluvial sedimentology. Vol. 5. Ch. Memoirs of the Canadian Society of Petroleum Geologists, pp. 313-341.

Lunt, I. A., Bridge, J. S., 2004. Evolution and deposits of a gravelly braid bar, sagavanirktok river, alaska. Sedimentology 51, 415-432.

Lunt, I. A., Bridge, J. S., Tye, R. S., 2004. A quantitative, three-dimentional model of gravelly braided rivers. Sedimentology 51, 377-414.

Luppi, L., Rinaldi, M., Teruggi, L. B., Darby, S. E., Nardi, L., 2009. Monitoring and numerical modelling of riverbank erosion processes: a case study along the cecina river (central italy). Earth Surface Processes and Landforms 34, 530-546. 
Mack, G. H., Leeder, M. R., Carothers-Durr, M., 2008. Modern flood deposition, erosion and fan-channel avulsion on the semiarid red canyon and palomas canyon alluvial fans in the southern rio grande rift, new mexico, u.s.a. Journal of Sedimentary Research 78, 432-442.

Mackin, H., 1948. Concept of the graded river. Bulletin of the Geological Society of America 59 (5), 463-512.

Maizels, J., 1989. Sedimentology, paleoflow dynamics and flood history of jökulhlaup deposits: Paleohydrology of holocene sediment sequences in southern iceland sandur deposits. Journal of Sedimentary Petrology 59, 204-223.

Maizels, J. K., 1983. Proglacial channel systems: change and thresholds for change over long, intermediate and short time-scales. In: Collison, J. D., Lewin, J. (Eds.), Modern and ancient fluvial systems. Vol. 6. Ch. Special Publications of the International Association of Sedimentologists, pp. 251-266.

Malde, H. E., 1968. The catastrophic late pleistocene bonneville flood in the snake river plain, idaho. USGS Professional Paper 596, 52.

Massari, F., 1983. Tabular cross-bedding in messinian fluvial channel conglomerates, southern alps, italy. In: Collison, J. D., Lewin, J. (Eds.), Modern and ancient fluvial systems. Vol. 6. Ch. Special Publications of the International Association of Sedimentologists, pp. $287-300$.

Massari, F., Mellere, D., Doglioni, C., 1993. Cyclicity in nan-marine foreland-basin sedimentary fill: The messinian conglomerate-bearing succession of the venitian alps (italy). In: Marzo, M., Puigdefábregas, C. (Eds.), Alluvial sedimentation. Vol. 17. Ch. Special Publications of the International Association of Sedimentologists, pp. 501-520.

McCandless, T. L., 2003. Maryland stream survey: Bankfull discharge and channel characteristics of streams in the coastal plain hydrologic region. Tech. rep.

McCandless, T. L., Everett, R. A., 2002. Maryland stream survey: bankfull discharge and channel characteristics of streams in the piedmont hydrologic region. us fish and wildlife service, chesapeake bay field office. Tech. rep.

McGowen, J. H., Garner, L. E., 1970. Physiographic features and stratification types of coarse-grained point bars: Modern and ancient examples. Sedimentology 14, 77-111.

Merigliano, M. F., 1997. Hydraulic geometry and stream channel behavior: A uncertain link 1. Journal of the American Water Resources Association 33 (6), 1327-1336.

Meunier, P., Métivier, F., Lajeunesse, E., Meriaux, A. S., Faure, J., Nov 2006. Flow pattern and sediment transport in a braided river: The torrent de St Pierre (French Alps). Journal of Hydrology 330, 496-505. 
Miall, A. D., 1977. A review of the braided river depositional environment. Earth Science Reviews 13, 1-62.

Miall, A. D., 1980. Cyclicity and the facies model concept in fluvial deposits. Bulletin of Canadian Petroleum Geology 28, 59-80.

Miall, A. D., 1984. Variations in fluvial style in the lower cenozoic synorogenic sediments of the canadian arctic islands. Sedimentary Geology 38, 499-523.

Miall, A. D., 1985. Architectural-element analysis: A new method of facies analysis applied to fluvial deposits. Earth Science Reviews 22, 261-308.

Miall, A. D., 1988. Facies architecture in clastic sedimentary basins. In: Kleinspehn, K. L., Paola, C. (Eds.), New perspectives in basin analysis. Springer-Verlag, pp. 67-81.

Miall, A. D., 1995. Description and interpretation of fluvial deposits: A critical perspective - discussion. Sedimentology 42, 379-384.

Miall, A. D., 1996. The geology of fluvial deposits: Sedimentary facies, basin analysis and petroleum geology. Springer.

Millar, R. G., 2000. Influence of bank vegetation on alluvial channel patterns. Water Resources Research 36 (4).

Millar, R. G., 2005. Theoretical regime equations for mobile gravel-bed rivers with stable banks. Geomorphology 64 (3-4), 207-220.

Millar, R. G., Quick, M. C., 1998. Stable width and depth of gravel-bed rivers with cohesive banks. Journal of Hydraulic Engineering 124 (10), 1005-1013.

Montgomery, D. R., Buffington, J. M., 1997. Channel-reach morphology in mountain drainage basins. Bulletin of the Geological Society of America 109 (5), 596-611.

Montgomery, D. R., Collins, B. D., Buffington, J. M., Abbe, T. B., 2003. Geomorphic effects of wood in rivers. In: American Fisheries Society Symposium. Vol. 37. pp. 21-47.

Moody-Stuart, M., 1966. High- and low-sinuosity stream deposits, with examples from the devonian of spitsbergen. Journal of Sedimentary Petrology 36, 1102-1117.

Mueller, E. R., Pitlick, J., 2005. Morphologically based model of bed load transport capacity in a headwater stream (doi 10.1029/2003jf000117). Journal of Geophysical Research-Earth Surface 110 (F2), 2016.

Murray, A. B., Paola, C., 2003. Modelling the effect of vegetation on channel pattern in bedload rivers. Earth Surface Processes and Landforms 28 (2).

Nakayama, K., Ulak, P., 1999. Evolution of fluvial style in the siwalik group in the foothills of the nepal himalaya. Sedimentary Geology 125, 205-224. 
Nami, M., Leeder, M. R., 1978. Changing channel morphology and magnitude in the scalby formation (middle jurassic) of yorkshire, england. In: Miall, A. D. (Ed.), Fluvial sedimentology. Vol. 5. Ch. Memoirs of the Canadian Society of Petroleum Geologists, pp. $431-440$.

Nijman, W., Puigdefabregas, C., 1978. Coarse-grained point bar structure in a molassetype fluvial system, eocene castisent sandstone formation, south pyrenean basin. In: Miall, A. D. (Ed.), Fluvial sedimentology. Vol. 5. Ch. Memoirs of the Canadian Society of Petroleum Geologists, pp. 487-510.

O'connor, J. E., Baker, V. R., 1992. Magnitudes and implications of peak discharges from glacial lake missoula. Geological Society of America Bulletin 104, 267-279.

Ori, G. G., 1982. Braided to meandering channel patterns in humid-region alluvial fan deposits, river reno, po plain (northern italy). Sedimentary Geology 31, 231-248.

Orton, G. J., Reading, H. G., 1993. Variability of deltaic processes in terms of sediment supply, with particular emphasis on grain size. Sedimentology 40, 475-512.

Osterkamp, W. R., Hedman, E. R., 1982. Perennial-streamflow characteristics related to channel geometry and sediment in missouri river basin. USGS Professional Paper 1242.

Paloa, C., Borgman, L., 1991. Reconstructing random topography from preserved stratification. Sedimentology 38, 553-565.

Paola, C., 2001. Modelling stream braiding over a range of scales. Gravel Bed Rivers V, 11-46.

Paola, C., Morhrig, D., 1996. Paleohydraulics revisited: Paleoslope estimation in coarsegrained braided rivers. Basin Research 8, 243-254.

Parker, C., Simon, A., Thorne, C. R., 2008. The effects of variability in bank material properties on riverbank stability: Goodwin creek, mississippi. Geomorphology 101 (4), $533-543$.

Parker, G., 1976. On the cause and characteristic scales of meandering and braiding in rivers. Journal of Fluid Mechanics 76 (3), 457-480.

Parker, G., 1978. Self-formed straight rivers with equilibrium banks and mobile bed. part 2. the gravel river. jfm 89, 127-146.

Parker, G., Wilcock, P., Paola, C., Dietrich, W. E., Pitlick, J., 2007. Quasi-universal relations for bankfull hydraulic geometry of single-thread gravel-bed rivers. Journal of Geophysical Research-Earth Surface 112, 1-21.

Piégay, H., Walling, D. E., Landon, N., He, Q., Liébault, F., Petiot, R., 2004. Contemporary changes in sediment yield in an alpine mountain basin due to afforestation (the upper drôme in france). Catena 55 (2), 183-212. 
Pollen-Bankhead, N., Simon, A., Jaeger, K., Wohl, E., 2009. Destabilization of streambanks by removal of invasive species in canyon de chelly national monument, arizona. Geomorphology 103 (3), 363-374.

Potter, P. E., 1959. Facies models conference. Science 129, 1292-1294.

Ramos, A., Sopeña, A., 1983. Gravel bars in low-sinuosity streams (permian and triassic, central spain). In: Collison, J. D., Lewin, J. (Eds.), Modern and ancient fluvial systems. Vol. 6. Ch. Special Publications of the International Association of Sedimentologists, pp. 301-312.

Reid, I., Laronne, J. B., Powel, D. M., 1995. The nahal yatir bedload database: sediment dynamics in a gravel-bed ephemeral stream. espl.

Rice, S. P., Church, M., Wooldridge, C. L., Hickin, E. J., 2009. Morphology and evolution of bars in a wandering gravel-bed river; lower fraser river, british columbia, canada. Sedimentology 56, 709-736.

Rinaldi, M., Mengoni, B., Luppi, L., Darby, S. E., Mosselman, E., 2008. Numerical simulation of hydrodynamics and bank erosion in a river bend. Water Resources Research 44 (9), 09428.

Robertson-Rintoul, M. S. E., Richards, K. S., 1993. Braided-channel pattern and paleohydrology using an index of total sinuosity. In: Best, J. L., Bristow, C. S. (Eds.), Braided rivers. Vol. 75. Ch. Special Publications of the Geological Society, pp. 113-118.

Rowntree, K. M., Dollar, E. S. J., 1996. Controls on channel form and channel change in the bell river, eastern cape, south africa. South African Geographical Journal 78, 20-28.

Rowntree, K. M., Dollar, E. S. J., 1999. vegetation controls on channel stability in the bell river, eastern cape, south africa. Earth Surface Processes and Landforms 24 (2), 127-134.

Rust, B. R., 1978a. A classification of alluvial channel systems. In: Miall, A. D. (Ed.), Fluvial sedimentology. Vol. 5. Ch. Memoirs of the Canadian Society of Petroleum Geologists, pp. $187-198$.

Rust, B. R., 1978b. Depositional models for braided alluvium. In: Miall, A. D. (Ed.), Fluvial sedimentology. Vol. 5. Ch. Memoirs of the Canadian Society of Petroleum Geologists, pp. 605-625.

Rust, B. R., 1979. Coarse alluvial deposits. In: Walker, R. G. (Ed.), Facies models. Vol. 1. Ch. Geosciences Canada Reprint Series, pp. 9-21.

Ryan, S. E., Emmett, W. W., 2002. The nature of flow and sediment movement in Little Granite Creek near Bondurant, Wyoming. Tech. rep., US Dep. Agr. 
Ryder, J. M., Church, M., 1986. The lillooet terraces of fraser river: A palaeoenvironmental enquiry. Canadian Journal of Earth Sciences 23, 869-884.

Schumm, S. A., 1960. The shape of alluvial channels in relation to sediment type: Us geol. US Geological Survey Prof. Paper 352-B, 17-30.

Schumm, S. A., 1963. A tentative classification of alluvial river channels. US Geological Survey Circular 477 (10).

Schumm, S. A., 1968a. River adjustment to altered hydrologic regimen-murrumbidgee river and paleochannels, australia: Us geol. Survey Prof. Paper 598, 65.

Schumm, S. A., 1968b. Speculation concerning paleohydrologic controls of terrestrial sedimentation. Geological Society of America Bulletin 79, 1573-1588.

Schumm, S. A., 1969. River metamorphosis. Journal of Hydraulics Division of the American Society of Civil Engineers 95, 255-273.

Schumm, S. A., 1972. Fluvial paleochannels. In: Rigby, J. K., Hamblin, W. K. (Eds.), Recognition of ancient sedimentary environments. Vol. 16. Ch. Special Publications of the Society of Economic Paleontologists and Mineralogists, pp. 98-107.

Schumm, S. A., 1977. The fluvial system. Publ. by: Wiley-Interscience.

Schumm, S. A., 1987. Experimental fluvial geomorphology. jws.

Schumm, S. A., 2005. River variability and complexity. Cambridge Univ Pr.

Shiono, K., Knight, D. W., 1991. Turbulent open-channel flows with variable depth across the channel. Journal of Fluid Mechanics 222, 617-646.

Siegenthaler, C., Huggenberger, P., 1993. Pleistocene rhine gravel: Deposits of a braided river system with dominant pool preservation. In: Best, J. L., Bristow, C. S. (Eds.), Braided rivers. Vol. 75. Ch. Special Publications of the Geological Society, pp. 147-162.

Simon, A., Collison, A. J. C., 2002. Quantifying the mechanical and hydrologic effects of riparian vegetation on streambank stability. Earth Surface Processes and Landforms 27 (5), $527-546$.

Simon, A., Curini, A., Darby, S. E., Langendoen, E. J., 2000. Bank and near-bank processes in an incised channel. Geomorphology 35 (3-4), 193-217.

Simon, A., Pollen, N., Langendoen, E., 2006. Influence of two woody riparian species on critical conditions for streambank stability: Upper truckee river, california. Journal of the American Water Resources Association 42 (1), 99-113.

Simon, A., Thomas, R. E., 2002. Processes and forms of an unstable system with resistant, cohesive streambeds. J. Earth Surface Processes and Landforms 27 (7), 699-718. 
Simpson, C. J., Smith, D. G., 2001. The braided milk river, northern montana, fails the leopold-wolman discharge-gradient test. Geomorphology 41 (4), 337-353.

Smith, D. G., 1976. Effect of vegetation on lateral migration of anastomosed channels of a glacier meltwater river. Bulletin of the Geological Society of America 87 (6), 857.

Smith, S. A., 1989. Sedimentation in a meandering gravel-bed river: The river tywi, south wales. Geological Journal 24, 193-204.

Smith, S. A., 1990. The sedimentology and accretionary styles of an ancient gravel-bed stream: the budleigh salterton pebble beds (lower triassic), southwest england. Sedimentary Geology 67, 199-219.

Steel, R. J., Thompson, D. B., 1983. Structures and textures in triassic braided stream conglomerates (bunter pebble beds) in the sherwood sandstone group, north staffordshire, england. Sedimentology 30, 341-367.

Steer, B. L., Abbott, P. L., 1984. Paleohydrology of the eocene ballena gravels, san diego county, california. Sedimentary Geology 38, 181-216.

Sylvia, D. A., Galloway, W. E., 2006. Morphology and stratigraphy of the late quaternary lower brazos alley: Implication for paleo-climate, discharge and sediment delivery. Sedimentary Geology 190, 159-175.

Tal, M., Paola, C., 2010. Effects of vegetation on channel morphodynamics: results and insights from laboratory experiments. Earth Surf. Proc. Landf.

Van De Wiel, M. J., Darby, S. E., 2007. A new model to analyse the impact of woody riparian vegetation on the geotechnical stability of riverbanks. Earth Surface Processes and Landforms 32 (14), 2185-2198.

van den Berg, J. H., 1995. Prediction of alluvial channel pattern of perennial rivers. Geomorphology 12 (4), 259-279.

Vanoni, V. A., 1940. Experiments on the transportation of suspended sediment by water. Ph.D. thesis, California Institute of Technology.

Vigilar, G. G., Diplas, P., 1997. Stable channels with mobile bed: formulation and numerical solution. Journal of Hydraulic Engineering 123, 189.

Walker, R. G., 1979. Facies and facies models: General introduction. In: Walker, R. G. (Ed.), Facies models. Vol. 1. Ch. Geosciences Canada Reprint Series, pp. 1-8.

Walter, R. C., Merritts, D. J., 2008. Natural streams and the legacy of water-powered mills. Science 319 (5861), 299.

Ward, P. D., Montgomery, D. R., Smith, R., 2000. Altered river morphology in south africa related to the permien-triassic extinction. Science 289, 1740-1735. 
Wilcock, P. R., 1996. Estimating local bed shear stress from velocity observations. Water Resources Research 32, 3361-3366.

Williams, G. P., 1984. Paleohydrologic equations for rivers. In: Costa, J. E., Fleisher, P. J. (Eds.), Developments and applications of geomorphology. Springer-Verlag, pp. 343-367.

Williams, G. P., 1988. Paleofluvial estimates from dimensions of former channels and meanders. In: Baker, V. R., Kochel, R. C., Patton, P. C. (Eds.), Flood geomorphology. John Wiley \& Sons, Ch. Special Publications of the Society of Economic Paleontologists and Mineralogists, pp. 321-334.

Williams, P. F., Rust, B. R., 1969. The sedimentology of a braided river. Journal of Sedimentary Petrology 39, 649-679.

Wohl, E., 2000. Mountain rivers. In: Water resources monograph 14. AGU.

Wohl, E., 2004. Limits of downstream hydraulic geometry. Geology 32 (10), 897-900.

Wooldridge, C. L., Hickin, E. J., 2005. Radar architecture and evolution of channel bars in wandering gravel-bed rivers: Fraser and squamish rivers, british columbia, canada. Journal of Sedimentary Research 75, 844-860.

Yalin, M. S., da Silva, A. M. F., 2001. Fluvial processes. IAHR (International Association of Hydraulic Engineering and Research), Delft.

Zimmerman, R. C., Goodlett, J. C., Comer, G. H., 1967. The influence of vegetation on channel form of small streams. IAHS Publication 75, 255-275. 